\title{
Electron microscopy of a 1991 spring plankton sample from the Argentinean Shelf reveals the presence of four new species of the Amphidomataceae (Dinophyceae)
}

\author{
Urban Tillmann (1D* \\ Department of Ecological Chemistry, Alfred Wegener Institute for Polar and Marine Research, Bremerhaven, Germany
}

\section{SUMMARY}

The dinophycean family Amphidomataceae encompasses the genera Azadinium and Amphidoma, which attract considerable attention because of their production potential for azaspiracids, i.e. lipophilic polyether phycotoxins. Many new species of Amphidomataceae were described in the last decade, but the diversity probably is not fully explored yet. In a continuation of a previous study, Amphidomatacean diversity of the 1991 spring plankton bloom along the Argentinean shelf was investigated. Based on morphology as inferred from scanning electron microscopy, three new species of Amphidoma and one new Azadinium are described. Azadinium asperum sp. nov. differed in size and shape from other Azadinium and had a characteristically rough and slightly granular surface of thecal plates. Amphidoma trioculata sp. nov. and Amphidoma cyclops sp. nov. differed by shape from most other Amphidoma, and can be differentiated from one another by the presence/absence of a antapical pore and by the size of a ventral depression. Amphidoma alata sp. nov. was unique by a conspicuous wing-like sulcal list. Calculations based on the total number of small dinoflagellates and on relative scanning electron microscopy quantification indicated that density of all four species was fairly high $\left(7-40 \times 10^{3}\right.$ cells $\left.\mathrm{L}^{-1}\right)$, so a large number of cells could be investigated in the sample. A few more single cells in the sample are attributable to Amphidomataceae but do not belong to one of the described species. This indicates that the diversity of the group is still not fully explored.

Key words: Amphidoma, Amphidoma alata sp. nov., Amphidoma cyclops sp. nov., Amphidoma trioculata sp. nov., Argentina, Azadinium, Azadinium asperum sp. nov.

\section{INTRODUCTION}

The family Amphidomataceae was erected in 1984 by Sournia with the single genus Amphidoma Stein of marine planktonic dinophytes. Previously, Amphidoma was placed in the Family Gonyaulacaceae (e.g. Schiller 1933), mainly because of the accordant hypothecal plate pattern (with six precingular plates and two slightly asymmetric antapical plates). However, Sournia (1984) considered the epithecal plate pattern of Amphidoma with six apical and six precingular plates to be sufficiently unique in the order Peridiniales to justify the creation of a new family. Amphidoma, with nine species described at that time by Stein (1883), Schiller (1929), Kofoid and Michener (1911) and Halldal (1953), was only rarely reported and poorly known, and was a sleeping beauty until Tillmann et al. (2009) described the genus Azadinium Elbrächter \& Tillmann. This introduction attracted attention because the type species, Azadinium spinosum Elbrächter \& Tillmann, was the first identified primary source of azaspiracids (AZAs), a group of lipophilic marine biotoxins associated with human incidents of shellfish poisoning. In the course of further detailed studies it became evident that one species of Amphidoma, A. caudata Halldal, has the same plate pattern as Azadinium spinosum, and this taxon was thus transferred from Amphidoma to Azadinium (Tillmann et al. 2011; Nézan et al. 2012). Furthermore, the morphological and molecular description of a new species of Amphidoma, Am. languida Tillmann, R. Salas \& Elbrächter, in 2012 clearly revealed a sister group relationship between Azadinium and Amphidoma; both are now classified in the family Amphidomataceae of yet undefined order designation (Tillmann et al. 2012). Toxin production is found in both genera, with AZA detected up to now in Az. spinosum (Tillmann et al. 2009), Az. poporum Tillmann \& Elbrächter (Krock et al. 2012), Az. dexteroporum Percopo \& Zingone (Rossi et al. 2017), and Am. languida (Krock et al. 2012).

Amphidomataceae are now known to be widely distributed in both south and north Pacific and Atlantic waters (Smith et al. 2016; Tillmann et al. 2016, 2017b; Kim et al. 2017; Tillmann 2018), and new records are continuously added (Tillmann et al. 2017c; Cavalcante et al. 2018). In many areas of the world, the presence of Amphidomataceae is accompanied by the detection of AZAs (Taleb et al. 2006; Amzil et al. 2008; Álvarez et al. 2010; Yao et al. 2010; Trainer et al. 2013; Bacchiocchi et al. 2015; Turner \& Goya 2015). In terms of abundance, the shelf break area off the Argentinean coast seems to be a 'hot spot' for Amphidomataceae as recurrent spring blooms of Azadinium dating back to the 1990s have been reported here (Akselman \& Negri 2012; Akselman et al. 2014). The bloom species was originally and tentatively described as $A z$. cf. spinosum (Akselman \& Negri 2012). However, a recent retrospective analysis of an archived bloom sample by scanning electron microscopy (SEM) (Tillmann \& Akselman 2016) revealed the presence and dominance of a newly described species, Az. lucifere/loides Tillmann \& Akselman. Moreover, the presence of

\footnotetext{
* To whom correspondence should be addressed.

Email: urban.tillmann@awi.de
}

Communicating Editor: Mitsunori Iwataki

Received 6 December 2017; accepted 7 March 2018. 
significant numbers of $A z$. spinosum, Az. dalianense Z. Luo, H. Gu \& Tillmann, Az. dexteroporum, and Am. languida also documented in this sample underscores the high diversity of Amphidomataceae in the austral Southwest Atlantic (Tillmann \& Akselman 2016). The present paper as a followup study now presents a detailed morphological description of several yet undescribed amphidomatacean species in this 1991 bloom sample.

\section{MATERIALS AND METHODS}

\section{Samples}

Plankton samples were collected during an oceanographic cruise (R/V Cap. Oca Balda, OB-05/91, INIDEP) conducted along a transect of approximately $300 \mathrm{~km}$ from the coast to oceanic waters across the northern Argentine Shelf in 12-13th September 1991. Water samples were obtained at standard depths by Niskin bottle casts and were fixed with Lugol's solution. Phytoplankton analysis was performed on a surface sample from a station located in the core of the Azadinium bloom detected during the cruise, i.e. St $2\left(38^{\circ} 41^{\prime} \mathrm{S}\right.$, 56 $06^{\circ}$ W) (see Akselman \& Negri 2012; their Fig. 1). After sedimentation in columns for quantitative studies, plankton material from a subsample was recovered and post-fixed with formalin ( $2 \%$ final concentration) for storage until analysis.

\section{Scanning electron microscopy}

For SEM, $0.5 \mathrm{~mL}$ of this dense concentrate of the subsample of station 2 fixed in approximately $2 \%$ formalin was used. Cells were collected on polycarbonate filters (Millipore, $25 \mathrm{~mm}$ diameter, $3 \mu \mathrm{m}$ pore-size) in a filter funnel where all subsequent washing and dehydration steps were carried out. Eight washings ( $2 \mathrm{~mL}$ deionized water each) were followed by a dehydration series in ethanol $(30,50,70,80,95,100 \%$; $10 \mathrm{~min}$ each). Filters were finally dehydrated with hexamethyldisilazane (HMDS), initially 1:1 HMDS : EtOH followed by $2 \times 100 \%$ HMDS, and stored under gentle vacuum in a desiccator. Filters were mounted on stubs, sputter coated (Emscope SC500, Ashford, UK) with gold-palladium and viewed under a scanning electron microscope (FEI Quanta FEG 200, Eindhoven, the Netherlands). SEM micrographs were presented on a black background using ADOBE PHOTOSHOP 6.0 (Adobe Systems, San Jose, CA, USA).

\section{RESULTS}

\section{Description of new species}

Amphidoma trioculata Tillmann sp. nov.

Figures 1-3, Fig. S4 in the Supporting Information.

Description. Marine thecate dinophyte, ovoid to broad elliptical and only scarcely dorso-ventrally compressed. Theca in SEM preparations $16.6-21.0 \mu \mathrm{m}$ long and 16.1-20.4 $\mu \mathrm{m}$

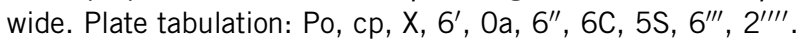
Lateral and dorsal apical plates small and approximately $1 / 5$ in length of precingular plates. A ventral pore on the right anterior margin of plate $1^{\prime}$ and an antapical pore on plate $2^{\prime \prime \prime \prime}$.
Holotype. Cell shown in Figure 1a, on SEM stub CEDiT2018H75, containing mixed plankton material (including also other amphidomatacean species reported here and by Tillmann and Akselman (2016) from station 2 (38 $41^{\prime} \mathrm{S}, 56^{\circ}$ $00^{\prime} \mathrm{W}$ ). The stub is deposited at the Senckenberg Research Institute and Natural History Museum, Centre of Excellence for Dinophyte Taxonomy, Germany.

Type locality. Argentinean middle shelf, approx. $150 \mathrm{~km}$ off the coast; coordinates: $38^{\circ} 41^{\prime} \mathrm{S}, 56^{\circ} 00^{\prime} \mathrm{W}$.

Etymology. The species epithet trioculata (Latin: with three eyes) reflect that this species has three distinct 'eyes', i.e. a ventral pore, an antapical pore, and a pore-like ventral depression.

\section{Detailed description}

Intact whole thecae of Amphidoma trioculata observed with SEM were ovoid to broad elliptical and were only scarcely dorso-ventrally compressed (Fig. 1a,b, Fig. S4 in the Supporting Information). Cell size as estimated from SEM photographs was $18.7 \mu \mathrm{m}$ in length $( \pm 1.5 \mathrm{SD}$, range: 16.6-21.0 $\mu \mathrm{m}, n=13)$ and $18.1 \mu \mathrm{m}$ in width ( $\pm 1.3 \mathrm{SD}$, range: $16.1-20.4 \mu \mathrm{m}, n=28$ ). The epitheca was domeshaped with slightly convex sides terminating in a distinct pointed apical pore complex. The hypotheca was hemispherical (Fig. 1a) to slightly conical (e.g. Fig. S4A in the Supporting Information). The cingulum was broad (corresponding to approximately $20 \%$ of cell length), impressed, and with minute cingular lists. The cingulum was displaced by approximately one-third of its width and was slightly sub-median so that the epitheca was only slightly longer than the hypotheca. The sulcal area was centrally located, running posterior to about half of the hypotheca, and was distinctly bordered on both sides by sulcal lists (Fig. 1a,b). The plate pattern was identified as APC (Po, cp, X), 6', 0a, 6", 6C, 5S, 6"', $2^{\prime \prime \prime \prime}$ (Fig. 2).

The epitheca consisted of 12 plates plus the apical pore complex (Fig. 1c). Six apical plates were located around the pore plate. The first apical plate $1^{\prime}$ was narrow and slightly asymmetric in its anterior part and had parallel sutures in its posterior part (Figs 1a,c,3a,b). On the anterior right side of $1^{\prime}$ there was a large pore (Fig. $3 b, c)$. This large pore of $0.32 \mu \mathrm{m}$ outer diameter $( \pm 0.04 \mu \mathrm{m}, n=12)$ with a special plate-like structure was regarded as the ventral pore. Because of the rim of plate $6^{\prime}$, this pore was often hidden and difficult to see.

Directly beneath the narrow contact of plate $1^{\prime}$ to the sulcal area there was a distinctly visible roundish depression (termed ventral depression) of $0.36 \mu \mathrm{m}$ diameter $( \pm 0.07 \mu \mathrm{m}$, $n=13$ ) (Figs $1 \mathrm{a}, 3 \mathrm{f}-\mathrm{h}$ ). The ventral depression in most cases was centrally located on the tip of plate Sa but occasionally was displaced to the left side (Fig. 3g). The lateral and ventral apical plates $2^{\prime}-6^{\prime}$ were small and roughly one-fifth the length of the precingular plates and were densely covered by thecal pores (Figs 1a,c,3a,b).

The APC was composed of three plates: a pore plate $(P o)$ covered by a cover plate ( $c p)$, and the canal plate $X$ (Fig. $3 a-c)$. The pore plate was round with a ventral elongation (length $2.40 \pm 0.13 \mu \mathrm{m}, \quad n=13$; $\quad$ width 

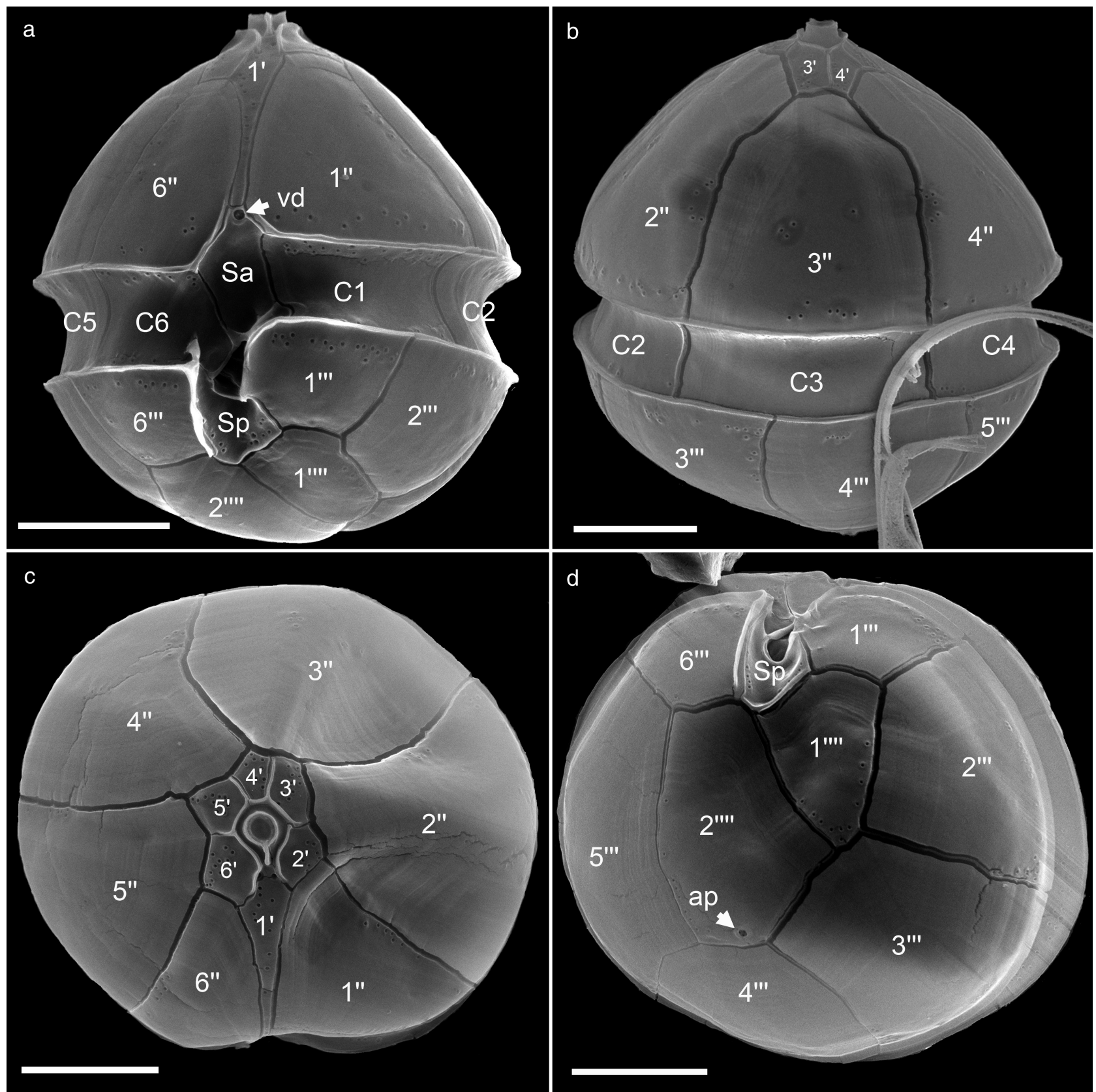

Fig. 1. Amphidoma trioculata sp. nov. SEM micrographs of different cells in (a) ventral view, (b) dorsal view, (c) apical view, and (d) antapical view. ap, antapical pore; vd, ventral depression. Scale bars: $5 \mu \mathrm{m}$.

$2.24 \pm 0.15 \mu \mathrm{m}, n=16$ ) and was bordered by a raised collar formed by the edges of the apical plates. On the ventral side, this collar was open but extended along the sutures between plate $1^{\prime}$ and its two joining apical plates $2^{\prime}$ and $6^{\prime}$ (Fig. 3a-c). Similar collars lined the sutures of other apical plates as well. They were formed by plates $3^{\prime}$ and $5^{\prime}$, whereas plate $4^{\prime}$ accounted for the collar towards the pore plate only (Figs 1c,3a,b). The apical pore in the center of the pore plate was almost circular (diameter $1.27 \pm 0.09 \mu \mathrm{m}, n=17$ ) and covered by a cover plate (cp).

Precingular plates (Fig. 1c) were large with the ventral plate 6 " being distinctly narrower compared to the others. All precingular plates were in contact with two of the apical plates.

There were six postcingular and two antapical plates on the hypotheca (Fig. 1d). Within the postcingular series plate $5^{\prime \prime \prime}$ was widest. The ventral postcingular plates $1^{\prime \prime \prime}$ and $6^{\prime \prime \prime}$ were distinctly smaller, tetragonal, and of comparable size (Fig. 1a,d). The second antapical plate $2^{\prime \prime \prime \prime}$ was about double the size of the first antapical plate (Fig. 1d) and bore a larger antapical pore close to the suture with plate $4^{\prime \prime \prime}$ (Figs 1d,3i). This circular structure (outer diameter $0.40 \pm 0.04 \mu \mathrm{m}$, $n=10$ ) was bordered by a broad rim and was an inwardly domed field of a small number $(<10)$ of small pores (Fig. 3i). 
a

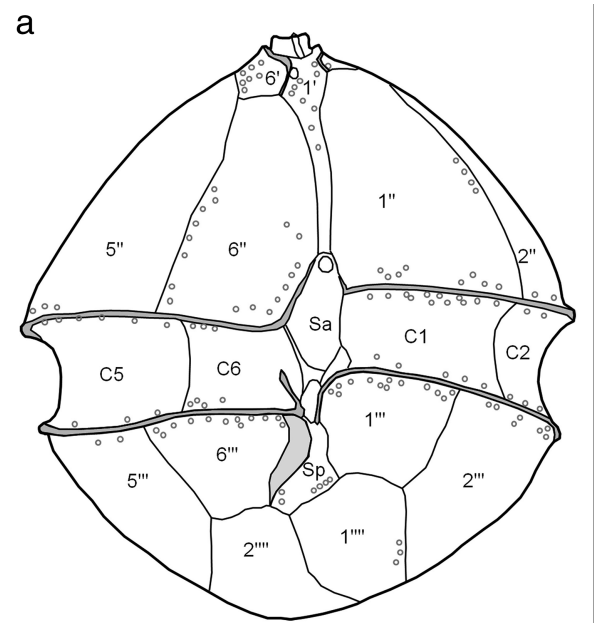

C

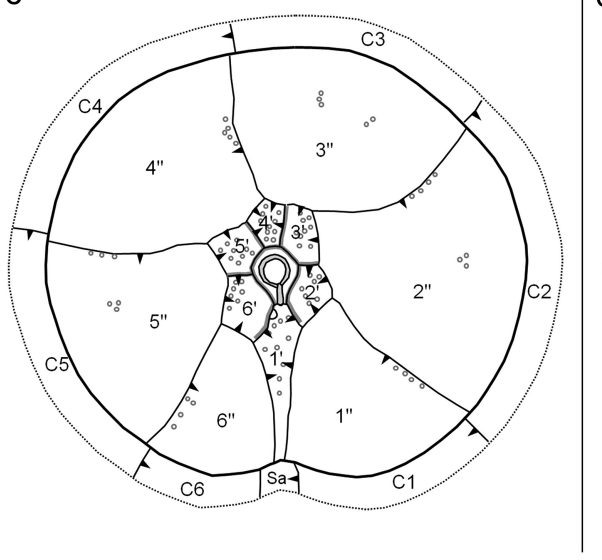

b

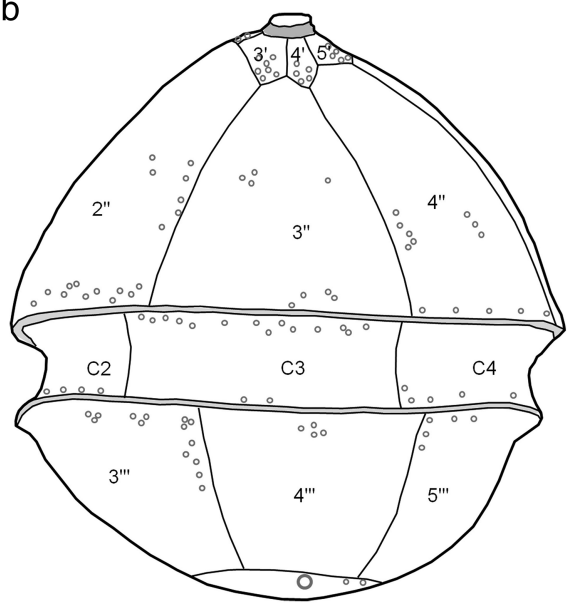

Fig. 2. Thecal plate pattern (schematic) of Amphidoma trioculata sp. nov. (a) Ventral view. (b) Dorsal view. (c) Apical view. (d) Antapical view. Plate labels according to the Kofoidian system. Abbreviations of sulcal plates: Sa, anterior sulcal plate; Sp, posterior sulcal plate. Arrowheads in $\mathrm{c}$ and d indicate direction of plate overlap.

There were six cingular plates (Fig. 1a,b). Five were of comparable size, but the right cingular plate $\mathrm{C} 6$ was distinctly narrower. All cingular plate sutures were nearly aligned with the respective sutures of precingular plates (Fig. 1a,b).

Within the sulcal area (Figs 1a,3d,e) there was an elongated anterior sulcal plate Sa, which only slightly invaded the epitheca. The posterior sulcal plate was inwardly arched. On its right side a sulcal list was running along the suture to plate $6^{\prime \prime \prime}$, and this list anteriorly was slightly invading the sixth cingular plate (Fig. 1a). The left sulcal list was shorter and restricted to the upper right side of plate $1^{\prime \prime \prime}$ (Fig. 1a). The morphology of the central sulcal area was difficult to resolve, because it was mostly hidden by the sulcal lists of plates $1^{\prime \prime \prime}$ and $6^{\prime \prime \prime}$. Two small plates forming the inverted part of the sulcus, namely a median sulcal (Sm) and a right sulcal (Sd) plate, were identified (Fig. 3d,e). A left sulcal plate (Ss) was visible in the left central sulcal area contacting plates $\mathrm{Sa}$ and $\mathrm{C} 1$. Its further rightwards extension, however, could not be resolved.

Plates were generally smooth, but broad and finely striated growth bands were visible mainly on pre- and postcingular plates (Fig. 1b-d). These growth bands were running along only particular sutures (i.e. along sutures of overlapping plates) from which the plate overlap pattern was deduced. Keystone plates were $3^{\prime \prime}, \mathrm{C} 3$, and $4^{\prime \prime \prime}$ in the precingular, cingular, and postcingular series, respectively. Among the apical plates, the dorsal plate $4^{\prime}$ was overlapped by all adjacent plates.
Almost all plates (plate Sa was an exception) bore a number of small pores of approximately $0.1 \mu \mathrm{m}$ diameter (Figs 13). There were about ten such pores on all apical plates. The number of pores on the precingular plates was 15-20 with the lowest number on the keystone plate $3^{\prime \prime}$. Likewise, keystone plate $4^{\prime \prime \prime}$ had the lowest number of pores of the postcingular series, normally about 10-20. Antapical plates and the posterior sulcal plate had about ten pores each (number and position of pores are schematically drawn in Fig. 2).

Among the 93 observed cells assigned to $\mathrm{Am}$. trioculata, two cells had a deviating plate arrangement/pattern (Fig. S8 in the Supporting Information). For one cell, the dorsal apical plate $4^{\prime}$ was slightly displaced dorsally and detached from the pore plate. Here the small suture of plates $3^{\prime}$ and $5^{\prime}$ would make plate $4^{\prime}$ formally to an anterior intercalary plate (Fig. S8A in the Supporting Information). For one fragment of an epitheca (likely representing $A m$. trioculata) there were only five apical plates present (Fig. S8B in the Supporting Information).

Amphidoma alata Tillmann sp. nov.

Figures 4-6, Fig. S5 in the Supporting Information.

Description. Marine thecate dinophyte, broadly biconical in outline, theca in SEM preparations 19.3-27.2 $\mu \mathrm{m}$ long and 17.0-23.0 $\mu \mathrm{m}$ wide. Plate tabulation: Po, cp, X, 6', Oa, 6", $6 \mathrm{C}, 5 \mathrm{~S}, 6^{\prime \prime \prime}, 2^{\prime \prime \prime \prime}$. Lateral and dorsal apical plates large and about the same length as precingular plates. No ventral 


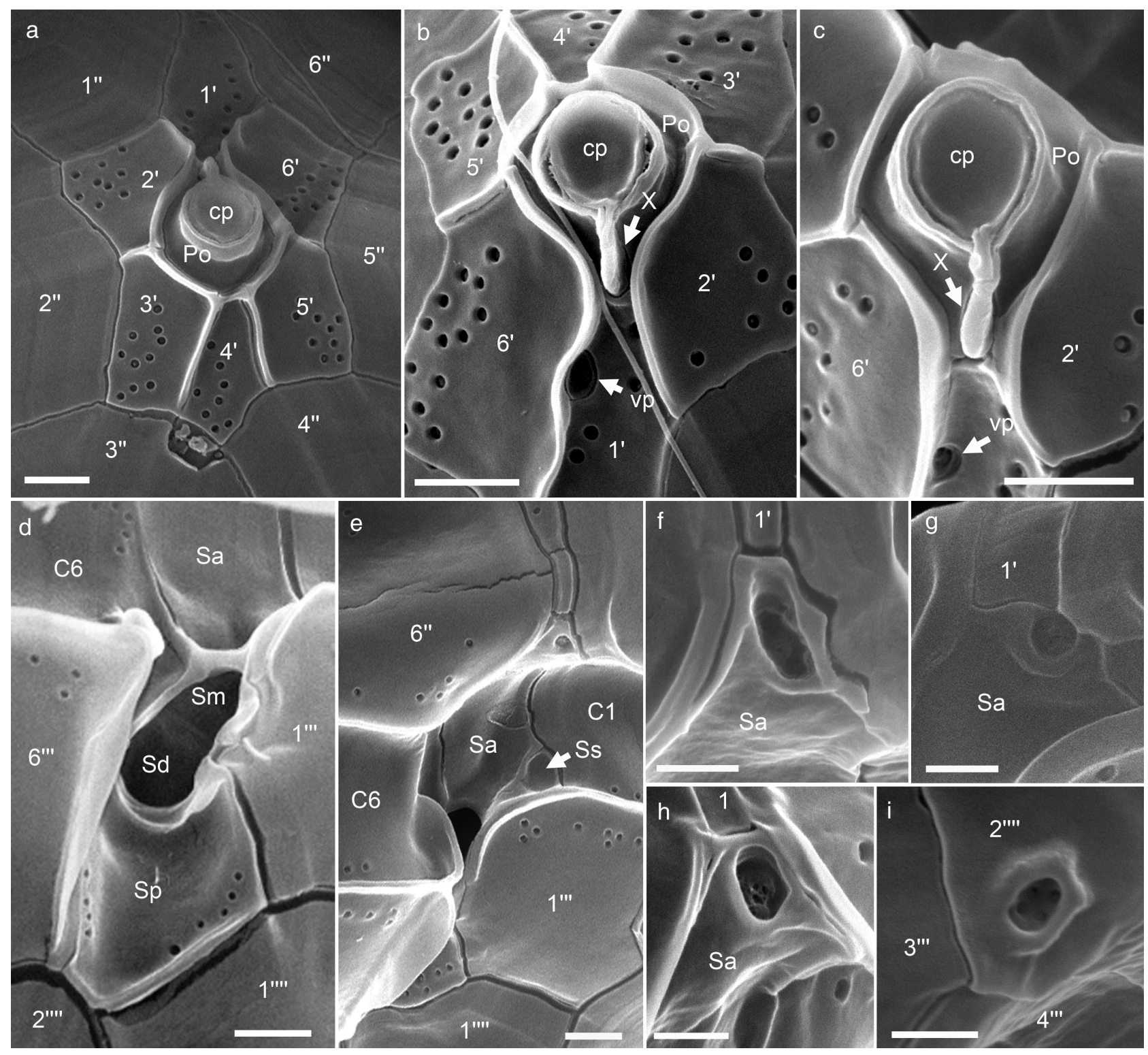

Fig. 3. Amphidoma trioculata sp. nov.: SEM micrographs of different cells. Apical plates and APC in dorsal (a) and ventral (b) view. (c) Detailed apical view of the APC. (d, e) Details of the sulcal plate arrangement. $(f-h)$ Detailed view of the anterior sulcal plate Sa showing variation in the ventral depression. (i) Detailed view of the antapical pore on plate $2^{\prime \prime \prime \prime}$. cp, cover plate; Po, pore plate; Sa, anterior sulcal plate; Sp, posterior sulcal plate; Ss, left sulcal plate; Sm, median sulcal plate; Sd, right sulcal plate; vp, ventral pore; X, X-plate. Scale bars: $1 \mu \mathrm{m}(\mathrm{a}-\mathrm{e})$ or $0.5 \mu \mathrm{m}(\mathrm{f}-\mathrm{i})$.

pore. Lateral and dorsal apical plates with row of pores bordered anteriorly by a ridge. Conspicuous broad and wing-like sulcal list running on the right side of the sulcus to the antapex.

Holotype. Cell shown in Figure $4 a$, on SEM stub CEDiT2018H76, containing mixed plankton material (including also other amphidomatacean species reported here and in Tillmann and Akselman (2016) from station 2 (38 41'S, 56 $\left.00^{\prime} \mathrm{W}\right)$. The stub is deposited at the Senckenberg Research Institute and Natural History Museum, Centre of Excellence for Dinophyte Taxonomy, Germany.
Type locality. Argentinean middle shelf, approximately $150 \mathrm{~km}$ off the coast; coordinates: $38^{\circ} 41^{\prime} \mathrm{S}, 56^{\circ} 00^{\prime} \mathrm{W}$.

Etymology. The epithet alata (Latin: winged, alate) refers to the large wing-like list running from the right sulcal side to the antapex.

\section{Detailed description}

Intact whole thecae of Amphidoma alata observed with SEM were broadly biconical and without marked dorso-ventral compression (Fig. 4, Fig. S5 in the Supporting Information) Cell size as estimated from SEM pictures was $21.8 \mu \mathrm{m}$ in length 

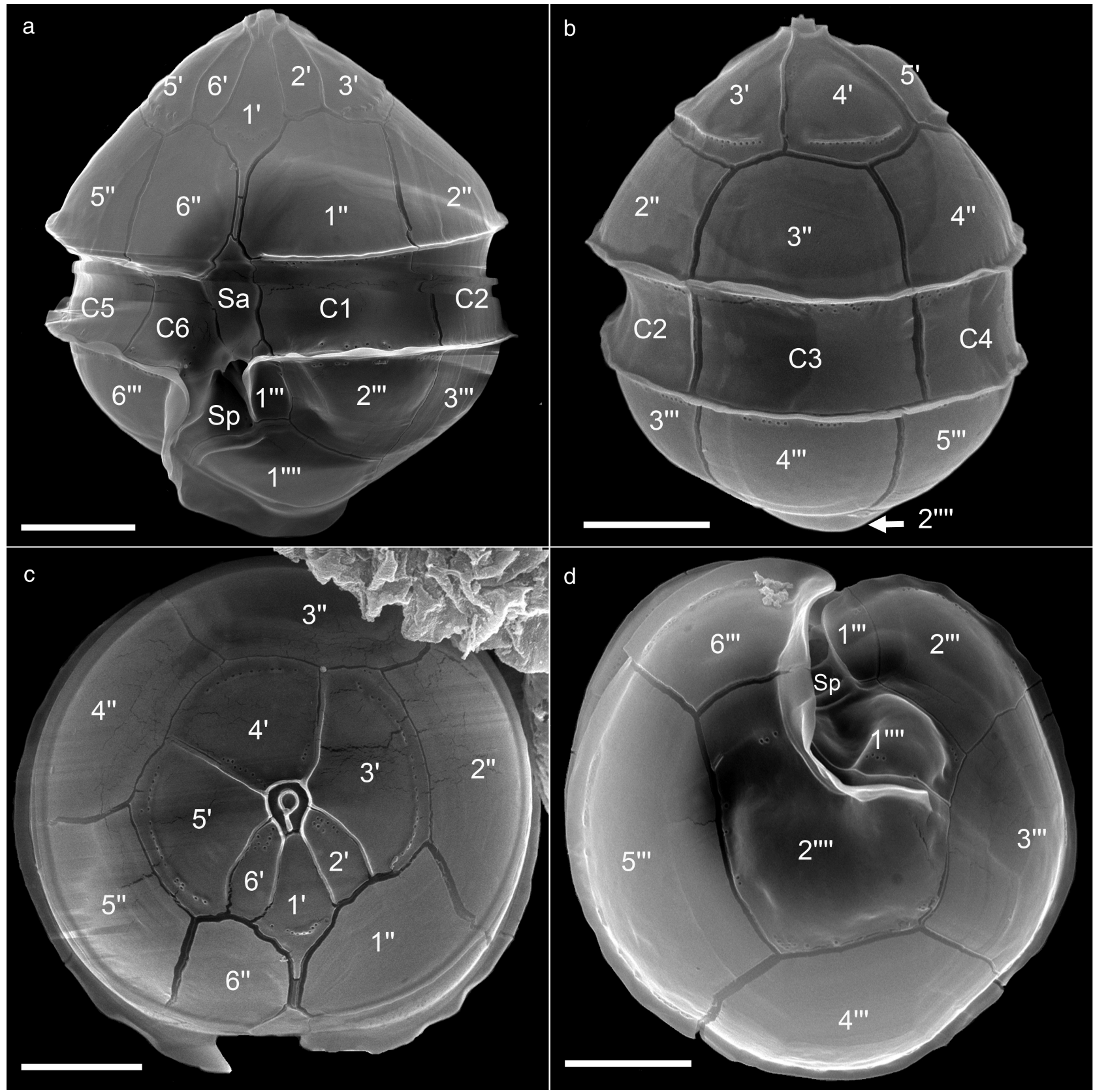

Fig. 4. Amphidoma alata sp. nov. SEM micrographs of different cells in (a) ventral view, (b) dorsal view, (c) apical view, and (d) antapical view. Scale bars: $5 \mu \mathrm{m}$.

( \pm 1.7 SD, range: $19.3-27.2 \mu \mathrm{m}, n=21$ ) and $20.0 \mu \mathrm{m}$ in width ( $\pm 1.4 \mathrm{SD}$, range: $17.0-23.0 \mu \mathrm{m}, \quad n=29)$. The epitheca was broadly conical with only scarcely convex sides and had a small but distinct apical pore complex (Fig. 4a,b). The hypotheca likewise was broadly conical with slightly convex sides. The cingulum was only marginally displaced, broad (about $20 \%$ of total cell length) and impressed, lined by cingular lists, and was almost in median position (Fig. 4a,b). The central sulcus was broad and dominated by a broad and winglike sulcal list on the right side. This list ran as an extension of the lower cingular list along the suture bordering on plate $6^{\prime \prime \prime}$ and continued on plate $2^{\prime \prime \prime \prime}$ along the antapex (Fig. 4a,d).
The Kofoidian plate pattern (APC (Po, cp, X), 6', Oa, 6" , 6C, $\left.5 \mathrm{~S}, 6^{\prime \prime \prime}, 2^{\prime \prime \prime \prime}\right)$ is depicted in Figure 5.

Next to the apical pore complex there were 12 epithecal plates in rows of six apical and six precingular plates (Fig. 4c). Apical plates were large and of roughly the same length as precingular plates (Fig. 4a,c). The first apical plate $1^{\prime}$ was diamond-shaped in its anterior part with a narrow elongated posterior part (Fig. 4a). The posterior part occasionally was very narrow (Fig. 6a) or even invisible, creating the impression of direct contact between plates $1^{\prime \prime}$ and $6^{\prime \prime}$ (Fig. 6b). Among the apical plates the three ventral plates $1^{\prime}$, $2^{\prime}$ and $6^{\prime}$ were narrow and the dorsal and lateral plates $3^{\prime}, 4^{\prime}$ 
Fig. 5. Thecal plate pattern (schematic) of Amphidoma alata sp. nov. (a) Ventral view. (b) Dorsal view. (c) Apical view. (d) Antapical view. Plate labels according to the Kofoidian system. Abbreviations of sulcal plates: Sa, anterior sulcal plate; Sp, posterior sulcal plate. Arrowheads in $c$ and $d$ indicate direction of plate overlap.

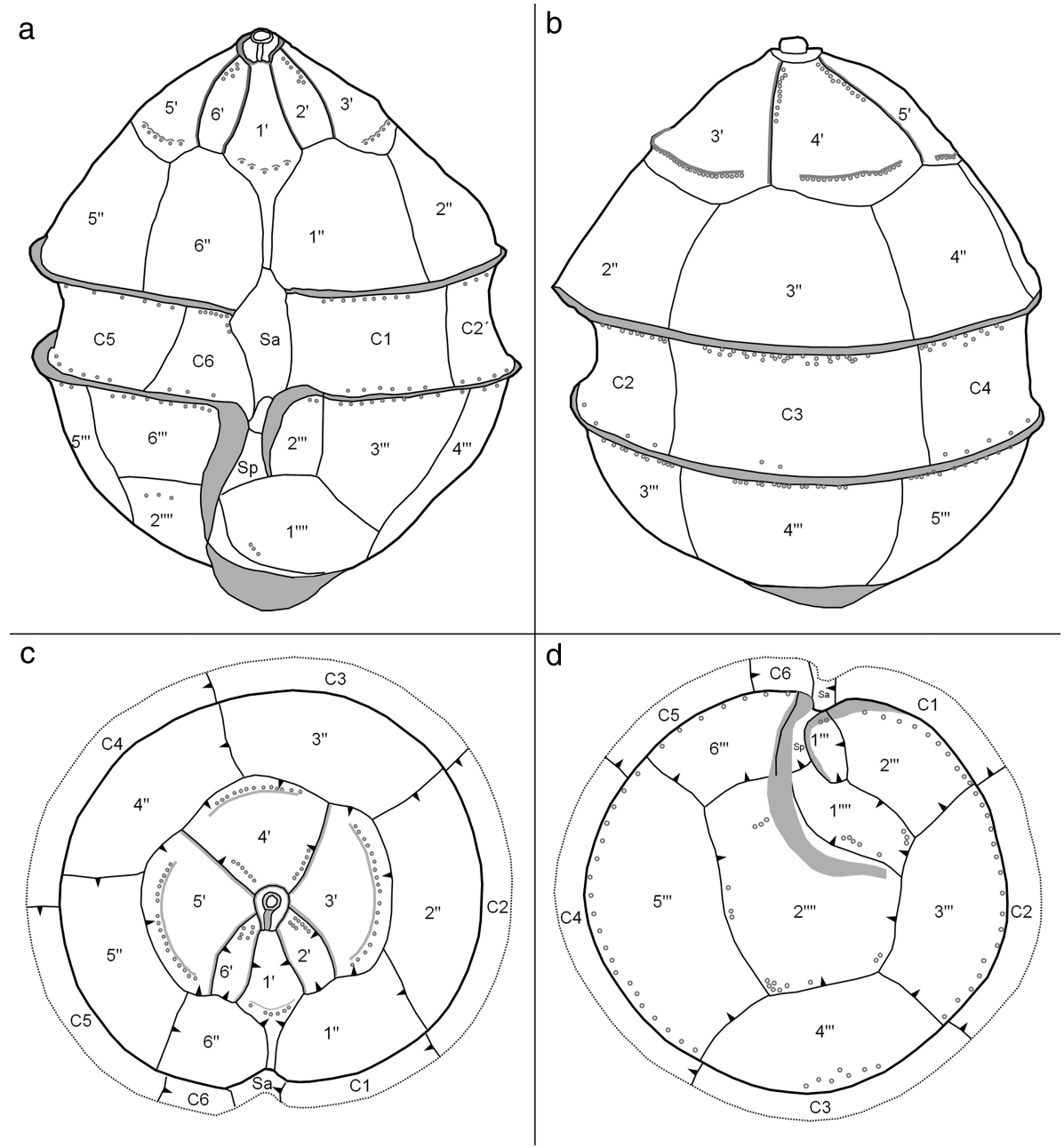

and $5^{\prime}$ were broad (Fig. 4c). The sutures of apical plates were lined by ridges, which were part of plates $3^{\prime}$ and $5^{\prime}$ towards plates $2^{\prime}, 4^{\prime}$, and $6^{\prime}$, and part of plates $2^{\prime}$ and $6^{\prime}$ towards the first apical plate (Fig. 4c).

The apical pore plate was ellipsoid (width: $1.85 \pm 0.19 \mu \mathrm{m}, n=9$; length: $2.07 \pm 0.25 \mu \mathrm{m}, n=3$ ) and had a roundish apical pore (diameter $0.83 \pm 0.10 \mu \mathrm{m}$, $n=11$ ) in the center, which was covered by a cover plate (Figs 4c,6c). The pore plate was bordered by a raised collar formed by the edges of the apical plates. On the ventral side the collar extended along the sutures between plate $1^{\prime}$ and its two joining apical pates $2^{\prime}$ and $6^{\prime}$ (Fig. $6 a, \mathrm{C}$ ). In the center of the suture of the pore plate to plate $1^{\prime}$ there was a small $X$ plate with characteristic three dimensional thin and finger-like protrusions contacting the apical cover plate (Fig. 6c). All precingular plates were of comparable width; only plate $6^{\prime \prime}$ was distinctly narrower. Both ventral precingular plates $1^{\prime \prime}$ and $6^{\prime \prime}$ were in contact with three apical plates, whereas their adjacent precingular plates $2^{\prime \prime}$ and $5^{\prime \prime}$ were in contact with only one apical plate. The dorsal precingular plates $3^{\prime \prime}$ and $4^{\prime \prime}$ were in contact with two apical plates each (Fig. 4c).

Six postcingular plates and two antapical plates of unequal size formed the hypotheca (Fig. 4d). The first postcingular plate $1^{\prime \prime \prime}$ was very narrow and only approximately one-third the width of plate $6^{\prime \prime \prime}$, whereas plate $5^{\prime \prime \prime}$ was the widest of the postcingular series (Fig. 4d). The left sulcal wing extended along the first postcingular plate to the suture of $1^{\prime \prime \prime}$ and $1^{\prime \prime \prime \prime}$ (Fig. 4a,d). On the right side the very broad and wing-like sulcal list extended from plate $6^{\prime \prime \prime}$ to the antapical plate $2^{\prime \prime \prime \prime}$, where it ran nearly the length of the growth band of the suture of plates $2^{\prime \prime \prime \prime}$ and $1^{\prime \prime \prime \prime}$ (Fig. 4a,d).

The six cingular plates were aligned with the respective precingular plates, and thus plate $\mathrm{C} 6$ was distinctly narrower compared to the other cingular plates (Fig. 4a,b). The asymmetrically rhomboid anterior sulcal plate slightly invaded the epitheca with its triangular acuminate anterior part (Fig. 4a). The posterior sulcal plate was deeply concave and its geometric shape could not be resolved. The central sulcal area was almost always obscured by the sulcal lists (Figs $4 a, 6 f, g$ ). A left sulcal plate was partly visible with its left anterior part (Figs $4 a, 6 f, g$ ). The fine structure of a central and inverted folded cavity could not be resolved.

Plates were generally smooth with the exception of broad and finely striated growth bands (e.g. Fig. S5B,F in the Supporting Information), the presence of ridges lining apical plate sutures (Fig. 4c), and characteristic rows of pores on some apical plates (Fig. 6d,e). Growth bands ran along only welldefined plate sutures from which the plate overlap pattern was deduced. Keystone plates were $3^{\prime \prime}, \mathrm{C} 3$, and $4^{\prime \prime \prime}$ of the precingular, cingular, and postcingular series, respectively 


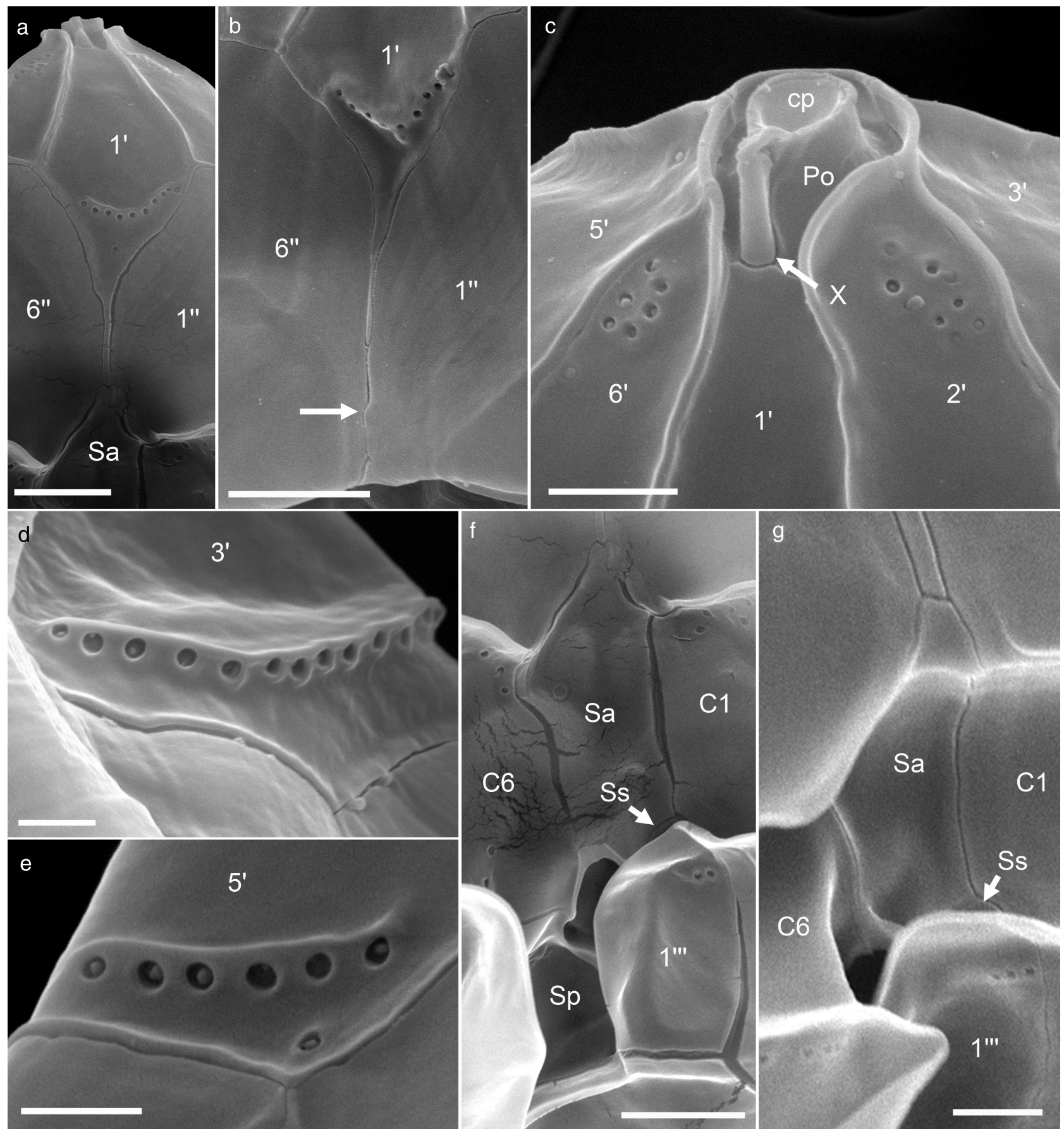

Fig. 6. Amphidoma alata sp. nov. SEM micrographs of different cells. (a, b) Detailed view of the first apical plate. Note that in (b) plates $1^{\prime \prime}$ and $6^{\prime \prime}$ had overgrown the narrow posterior part of $1^{\prime}$ (white arrow). (c) Detailed view of the APC in ventral view. (d, e) Detailed view of the row of pores bordered by a ridge on plate $3^{\prime}(\mathrm{d})$ and $5^{\prime}(\mathrm{e})$. (f, g) Details of the sulcal plate arrangement. $c p$, cover plate; Po, pore plate; Sa, anterior sulcal plate; Sp, posterior sulcal plate; X, X-plate. Scale bars: $2 \mu \mathrm{m}(a, b, f, g)$ or $1 \mu \mathrm{m}$ (c-e).

(Fig. 5c,d). Among the apical plates, the dorsal plate $4^{\prime}$ was overlapped by all adjacent plates. Most plates had a number of small thecal pores of about $0.1 \mu \mathrm{m}$ diameter, whose distribution on some of the plates was rather characteristic (Fig. 6). The narrow ventral apical plates $2^{\prime}$ and $6^{\prime}$ had about 6-8 anteriorly located pores. The large dorsal and lateral apical plates and the first apical plate as well had a characteristic and almost linear row of pores, which was more or less distinctly bordered anteriorly by a ridge (Figs 4b,6d,e). The dorsal plate $4^{\prime}$ additionally had rows of pores along the sutures to the adjacent apical plates $3^{\prime}$ and $5^{\prime}$ (Fig. 4c). Precingular plates were consistently free of pores, and postcingular plates had rows of pores close to the cingulum. Both antapical plates had a few pores lined along some plate 
sutures or growth bands. No pores were found on the anterior sulcal plate, whereas the posterior sulcal plate had a low number of pores (Fig. 5).

Among the 96 cells determined as Am. alata there was one cell with a deviating plate number. It had seven apical plates (Fig. S8C in the Supporting Information), likely caused by an extra suture in plate $4^{\prime}$ and a reduction of size of the lateral plates $3^{\prime}$ and $5^{\prime}$.

Amphidoma cyclops Tillmann sp. nov.

Figures 7-9, Fig. $\mathrm{S} 6$ in the Supporting Information.
Description. Marine thecate dinophyte with ovoid shape, theca in SEM preparations 15.9-22.3 $\mu \mathrm{m}$ long and 14.3-20.7 $\mu \mathrm{m}$ wide. Plate tabulation: Po, cp, X, 6', Oa, 6", $6 \mathrm{C}, 5 \mathrm{~S}, 6^{\prime \prime \prime}, 2^{\prime \prime \prime \prime}$. Lateral and dorsal apical plates small and approximately $1 / 5$ the length of precingular plates. Anterior sulcal plate Sa with an elongated anterior part bearing a large roundish ventral depression. Hypotheca with list-like thickenings lining a number of sutures of both antapical plates.

Holotype. Cell shown in Figure 7a, on SEM stub CEDiT2018H77, containing mixed plankton material
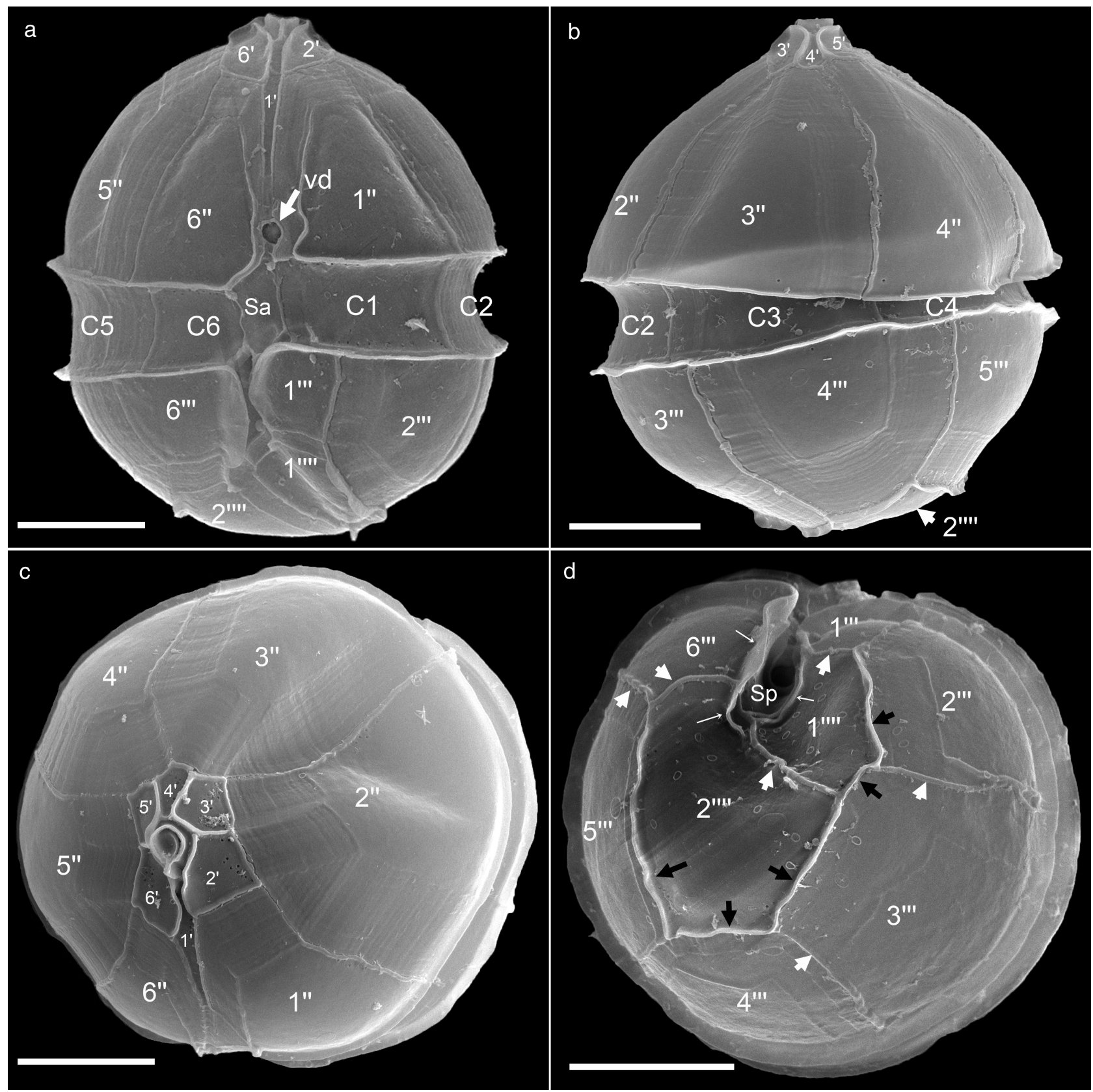

Fig. 7. Amphidoma cyclops sp. nov. SEM micrographs of different cells in (a) ventral view, (b) dorsal view, (c) apical view, and (d) antapical view. White arrows: ridge-like structures on the hypotheca lining plate sutures. Black arrows: minute list-like thickenings lining a number of sutures along the border of both antapical plates. Small white arrows: small lists continuing the right and left sulcal lists and partly lining the growth band of plate $2^{\prime \prime \prime \prime}$ and $1^{\prime \prime \prime \prime}$. vp, ventral depression. Scale bars: $5 \mu \mathrm{m}$. 


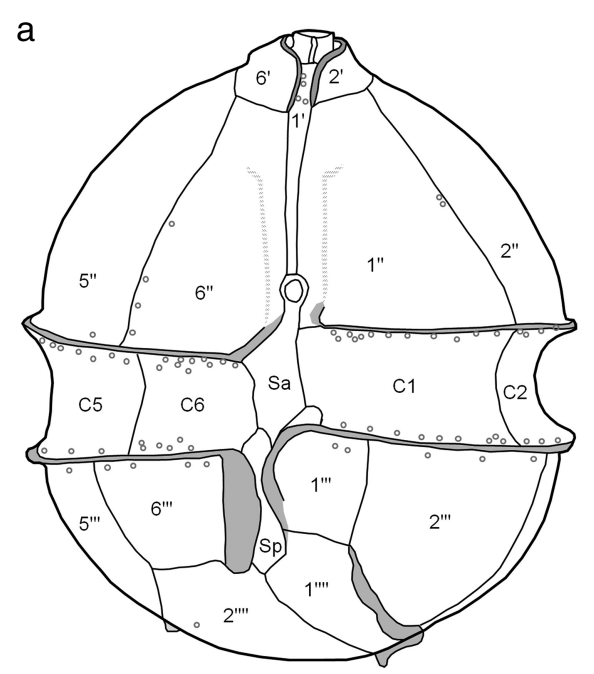

b

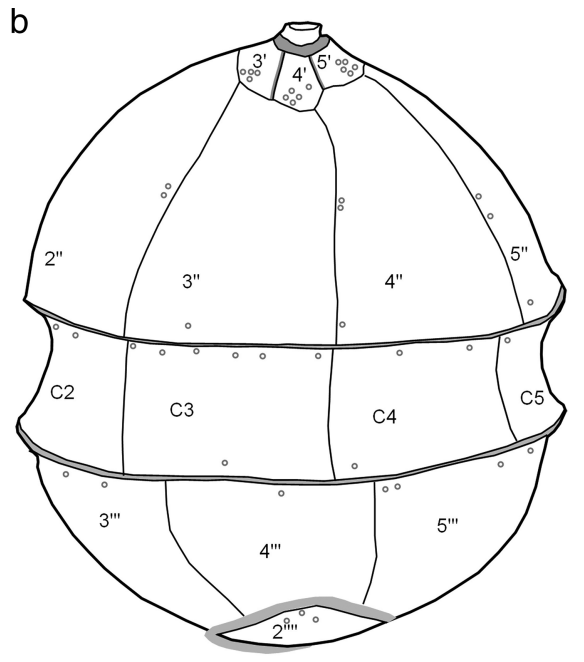

$\mathrm{C}$
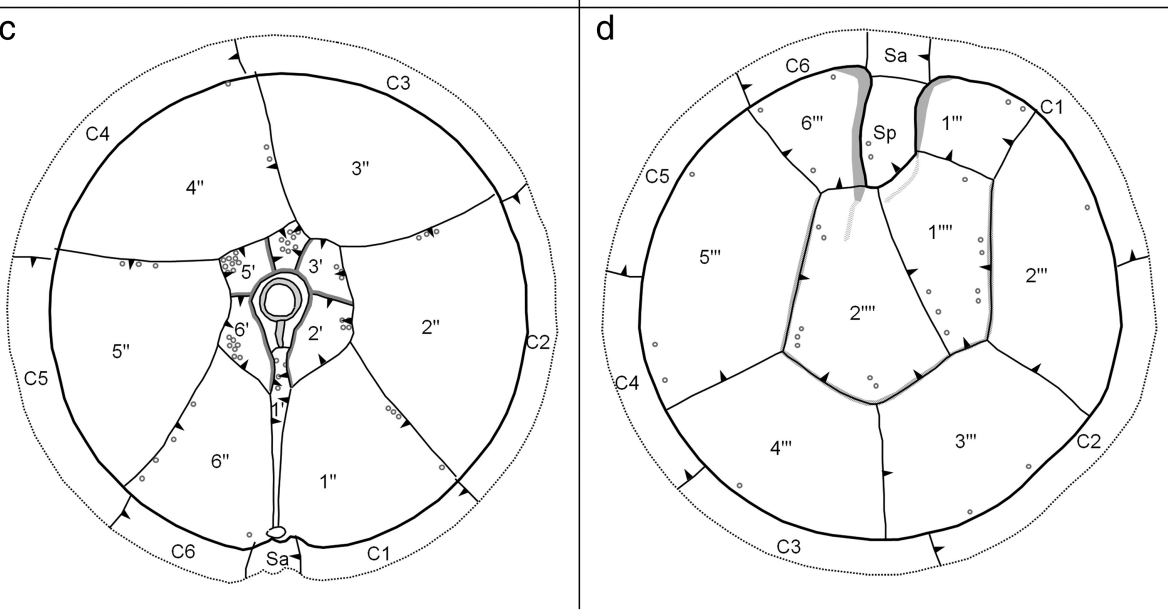

Fig. 8. Thecal plate pattern (schematic) of Amphidoma cyclops sp. nov. (a) Ventral view. (b) Dorsal view. (c) Apical view. (d) Antapical view. Plate labels according to the Kofoidian system. Abbreviations of sulcal plates: Sa, anterior sulcal plate; Sp, posterior sulcal plate. Arrowheads in $c$ and $d$ indicate direction of plate overlap. (including also other amphidomatacean species reported here and by Tillmann and Akselman (2016) from station 2 (38 $\left.41^{\prime} \mathrm{S}, 56^{\circ} 00^{\prime} \mathrm{W}\right)$. The stub is deposited at the Senckenberg Research Institute and Natural History Museum, Centre of Excellence for Dinophyte Taxonomy, Germany.

Type locality. Argentinean middle shelf, approximately $150 \mathrm{~km}$ off the coast; coordinates: $38^{\circ} 41^{\prime} \mathrm{S}, 56^{\circ} 00^{\prime} \mathrm{W}$.

Etymology. The epithet cyclops (Latin noun for Cyclopes, the one-eyed legendary figures of the Greek mythology) refers to the central large 'eye-like' ventral depression of the species.

\section{Detailed description}

Intact whole thecae of Amphidoma cyclops observed with SEM were ovoid in shape (Fig. 7, Fig. S6 in the Supporting Information). Cell size as estimated from SEM pictures was $18.6 \mu \mathrm{m}$ in length ( $\pm 1.5 \mathrm{SD}$, range: $15.9-22.3 \mu \mathrm{m}, n=25$ ) and $17.1 \mu \mathrm{m}$ in width $( \pm 1.4 \mathrm{SD}$, range: $14.3-20.7 \mu \mathrm{m}, n$ $=40$ ). The hemispherical to dome-shaped epitheca and the hemispherical to broadly rounded hypotheca were separated by a broad and indented cingulum (Fig. 7a,b). The cingulum was about $20 \%$ of cell length, slightly displaced and lined by minor cingular lists. The epitheca was slightly longer than the hypotheca and terminated in a pointed apical pore complex. A narrow sulcus extended about halfway down the hypotheca and was largely hidden by sulcal lists. The anterior sulcal plate Sa with a narrow anterior part slightly invaded the epitheca and terminated with a conspicuous large and round (diameter: $0.78 \pm 0.14 \mu \mathrm{m}, n=8$ ) ventral depression (Fig. 7a). The Kofoidian plate pattern (APC (Po, $\left.\mathrm{cp}, \mathrm{X}), 6^{\prime}, 0 \mathrm{a}, 6^{\prime \prime}, 6 \mathrm{C}, 5 \mathrm{~S}, 6^{\prime \prime \prime}, 2^{\prime \prime \prime \prime}\right)$ is schematically drawn in Figure 8.

The epitheca contained the apical pore complex and rows of six apical and precingular plates each (Fig. 7c). The first apical plate was narrow and only slightly broader in its anterior part (Fig. 7a,C). Its sutures to the adjacent precingular plates were lined by ridges (Fig. 7a). In addition, the ventral precingular plates bore list-like extensions of the cingular list lining the growth band (Fig. 7a). The lateral and dorsal apical plates were small and only about one-fifth the length of precingular plates (Fig. 7a-C). They were all five-sided implying that each precingular plate was in contact with two apical plates. All sutures between apical plates were marked by ridges which were part of plates $3^{\prime}$ and $5^{\prime}$ and by plates $2^{\prime}$ and $6^{\prime}$ towards the first apical plate (Figs 7c,9a,b). Precingular plates were of comparable size with the ventral plates $1^{\prime \prime}$ and $6^{\prime \prime}$ slightly narrower compared to the others (Fig. 7c). 
The apical pore plate (Figs 7c,9a,b) was almost round with only a short ventral extension (length: $2.23 \pm 0.12 \mu \mathrm{m}, n$ = 3; width: $2.27 \pm 0.07 \mu \mathrm{m}, n=9$ ). The apical pore in the center of the pore plate was roundish (diameter: $1.26 \pm 0.07 \mu \mathrm{m}, n=9$ ) and covered with a cover plate. The pore plate was bordered by a raised collar formed by the edges of the apical plates, which ventrally extended along the sutures between plate $1^{\prime}$ and its two joining apical plates $2^{\prime}$ and $6^{\prime}$ (Fig. 9a,b).
Among postcingular plates, plate $3^{\prime \prime \prime}$ and $5^{\prime \prime \prime}$ were the largest, whereas the ventral plates $1^{\prime \prime \prime}$ and $6^{\prime \prime \prime}$ were the smallest (Fig. 7d). Plate $1^{\prime \prime \prime}$ was small, squarish, and slightly but distinctly narrower than plate $6^{\prime \prime \prime}$. The two antapical plates were unequal in size, with plate $2^{\prime \prime \prime \prime}$ being distinctly larger. As it was the case for the epitheca there were a number of ridgelike structures on the hypotheca lining plate sutures (Fig. 7d, white arrows). In addition, minute list-like thickenings lined a number of sutures and growth bands, i.e. along the border of

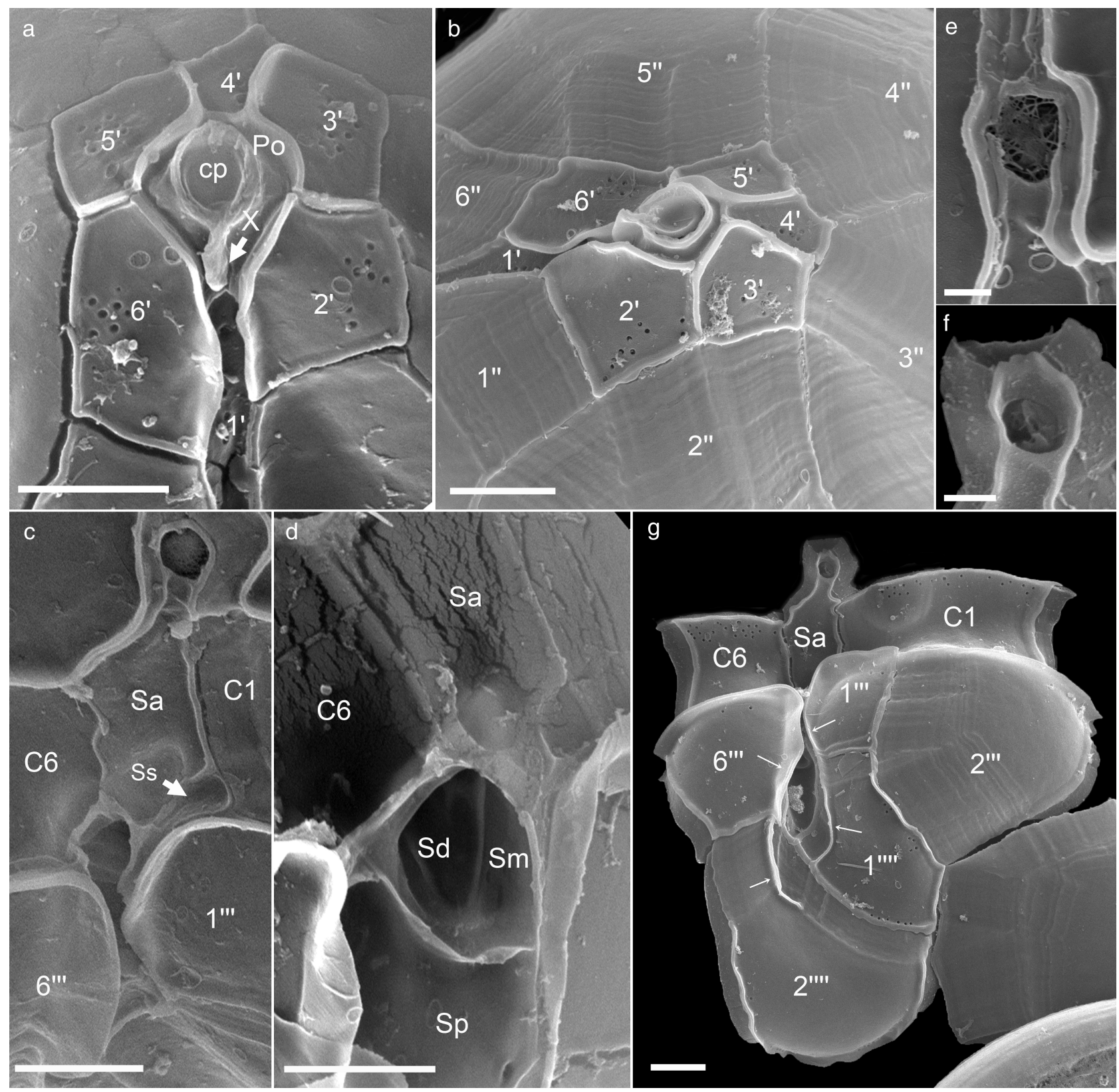

Fig. 9. Amphidoma cyclops sp. nov.: SEM micrographs of different cells. Apical plates and APC in apical (a) and left lateral (b) view. (c, d) Details of the sulcal plate arrangement. (e, $f$ ) Detailed view of the anterior part of the sulcal plate Sa showing the ventral depression. (g) Detailed view of the central sulcal and hypothecal area showing the large ventral depression at the anterior tip of plate Sa and the left and right sulcal list partly lining the growth bands of plate $2^{\prime \prime \prime \prime}$ and $1^{\prime \prime \prime \prime}$ (small white arrows). cp, cover plate; Po, pore plate; Sa, anterior sulcal plate; Sp, posterior sulcal plate; Ss, left sulcal plate; Sm, median sulcal plate; Sd, right sulcal plate; X, X-plate. Scale bars: $2 \mu \mathrm{m}$ (a-d, g) or $0.5 \mu \mathrm{m}(e, f)$. 
$1^{\prime \prime \prime \prime}$ with both $2^{\prime \prime \prime}$ and $3^{\prime \prime \prime}$, and the borders of $2^{\prime \prime \prime \prime}$ with precingular plates $3^{\prime \prime \prime}, 4^{\prime \prime \prime}$ and $5^{\prime \prime \prime}$ (Fig. 7d, black arrows). Moreover, there was a small list continuing the right sulcal list and partly lining the growth band of plate $2^{\prime \prime \prime \prime}$. A similar structure was visible as an extension of the left sulcal list along the growth band of plate $1^{\prime \prime \prime \prime}$ (Figs 7d,9g, small white arrows).

Six plates formed the cingulum. Plate C6 was distinctly narrower but the other cingular plates were of comparable size. Cingular plates were aligned in position with their respective precingular plates (Fig. 7a,b).

The sulcus was dominated by the large anterior sulcal plate (bearing the large ventral depression, Fig. 9c,e-g) and a large but deeply concave posterior sulcal plate (Figs 7a,9c,d, g). Other sulcal plates of the central sulcal area were mostly hidden by the sulcal lists and thus difficult to observe. A left sulcal plate (Ss) was visible in the left central sulcal area contacting plate $\mathrm{Sa}$ and $\mathrm{C} 1$ and running along the plate $1^{\prime \prime \prime}$ (Fig. 9c). Its further extension in the central sulcal area could not be resolved. Two small plates ( $\mathrm{Sm}$ and $\mathrm{Sd}$ ) formed the inverted central part of the sulcus (Fig. 9d).

Plates were generally smooth with a number of small thecal pores and thickened ridges along some sutures and/or growth bands. Broad growth bands were finely striated and ran along only certain plate sutures (Fig. 7a-c). The correspondingly deduced plate overlap pattern indicated plates $3^{\prime \prime}, \mathrm{C} 3$, and $4^{\prime \prime \prime}$ as keystone plates (Fig. 8c,d). Among the apical plates, the dorsal plate $4^{\prime}$ was overlapped by all adjacent plates. Thecal pores were slightly variable in size but generally about $0.1 \mu \mathrm{m}$ in diameter. Pores were most densely located on the apical plates, which had about 3-10 pores per plate. Precingular plates had only very few (2-5) pores located along the plate sutures. The keystone plate $3^{\prime \prime}$ had no or occasionally one single thecal pore. All plates of the hypotheca had a small number (1-8) of pores located along the sutures with adjoining plates. No pores were seen on the anterior sulcal plate (Fig. 8).

There were 51 cells identified as Am. cyclops in the sample, and among them, there was one epitheca fragment with only five apical plates, interpreted here as a fusion of plates $4^{\prime}$ and $5^{\prime}$. This cell had very broad growth bands on precingular plates and was unique in the presence of additional ridges on the apical plates (Fig. S8D in the Supporting Information).

Azadinium asperum Tillmann sp. nov.

Figures 10-12, Fig. S7 in the Supporting Information.

Description. Marine thecate dinophyte, theca in SEM preparations 21.1-26.0 $\mu \mathrm{m}$ long and 17.4-21.6 $\mu \mathrm{m}$ wide. Epitheca conical, hypotheca broadly conical or rounded, with a small antapical spine on the left side of plate $2^{\prime \prime \prime \prime}$. Plate tabulation: Po, cp, X, 4', 3a, 6" $6 \mathrm{C}, 5 \mathrm{~S}, 6^{\prime \prime \prime}, 2^{\prime \prime \prime \prime}$. A ventral pore located on the anterior left side of plate $1^{\prime}$ next to the suture with plate $2^{\prime}$. Surface of thecal plates rough and slightly granular.

Holotype. Cell shown in Figure 10 a on SEM stub CEDiT2018H78, containing mixed plankton material (including also other amphidomatacean species reported here and by Tillmann and Akselman (2016) from station 2 (38 41'S, 56 $00^{\prime} \mathrm{W}$ ). The stub is deposited at the Senckenberg Research Institute and Natural History Museum, Centre of Excellence for Dinophyte Taxonomy, Germany.
Type locality. Argentinean middle shelf, approximately $150 \mathrm{~km}$ off the coast; coordinates: $38^{\circ} 41^{\prime} \mathrm{S}, 56^{\circ} 00^{\prime} \mathrm{W}$.

Etymology. The species epithet asperum (Latin: asperus: rough) is inspired by the rough and slightly granular surface of the thecal plates compared to the smooth surface of all other described species of Azadinium.

\section{Detailed description}

Intact whole thecae of Azadinium asperum observed with SEM were biconical (Fig. 10a,b). Cell size as estimated from SEM pictures was $24.3 \mu \mathrm{m}$ in length $( \pm 1.4 \mathrm{SD}$, range: 21.1-26.0 $\mu \mathrm{m}, n=12$ ) and $19.7 \mu \mathrm{m}$ in width ( $\pm 1.5 \mathrm{SD}$, range: $17.4-21.6 \mu \mathrm{m}, n=9$ ). The conical epitheca with slightly convex sides ended in a pointed apical pore complex. The broadly conical hypotheca was broadly rounded at the antapex and terminated in a small antapical spine. The broad and incised cingulum was near the middle of the cell and comprised about $15 \%$ of total cell length. It was lined by small cingular lists. The sulcus was broad and broadened posteriorly, lined by sulcal lists, and extended to about two-third of the hypotheca. The anterior sulcal plate slightly invaded the epitheca. The Kofoidian plate pattern (Po, cp, X, 4', 3a, $\left.6^{\prime \prime}, 6 \mathrm{C}, 5 \mathrm{~S}, 6^{\prime \prime \prime}, 2^{\prime \prime \prime \prime}\right)$ is schematically drawn in Figure 11.

The epitheca was composed of six precingular plates, three anterior intercalary plates, four apical plates, and an apical pore complex (Fig. 10c). The first apical plate was diamond shaped in the upper part and narrow with parallel sutures in the lower part (Fig. 10a). In the left anterior part on the suture to plate $2^{\prime}$ there was a ventral pore (outer diameter: $0.41 \pm 0.05 \mu \mathrm{m}, n=8$ ) with the plate-like substructure typical for other species of Azadinium (Figs 10a,12a,b). The ventral pore was placed slightly inside of plate $1^{\prime}$ but was connected to the suture to plate $2^{\prime}$ by a narrow slit (Fig. 12a). Of the lateral apical plates, plate $2^{\prime}$ was five-sided and plate $4^{\prime}$ was six-sided. The symmetrical dorsal apical plate $3^{\prime}$ was six-sided (Fig. 10c). There were three anterior intercalary plates (Figs 10b,12d). The left (1a) and right (3a) plates were relatively larger than the small and tetragonal mid intercalary plate 2a. Among the six precingular plates, plate $3^{\prime \prime}$ to $5^{\prime \prime}$ were of comparable size, and the ventral plates $1^{\prime \prime}$ and $6^{\prime \prime}$ were narrower with plate $6^{\prime \prime}$ being the narrowest (Fig. 10a,c). The plate arrangement of the left ventral side was variable. In six of eight cells where this area was clearly visible, plate $1^{\prime \prime}$ was in contact with plate 1a (Figs 10c,12b). For the other two cells, however, there was no such contact (arrow in Fig. 12c).

The pore plate was ellipsoid with a straight line where the first apical plate abutted the pore plate. In the center there was a round apical pore (diameter: $1.18 \pm 0.05 \mu \mathrm{m}, n=5$ ) covered by a cover plate (Figs 10c,12b). The dorsal and lateral margins of the pore plate to the apical plates $2^{\prime}$ to $4^{\prime}$ were made by a broad rim (Figs $10 \mathrm{c}, 12 \mathrm{a}-\mathrm{c}$ ). The same rim-like structure located on plates $2^{\prime}$ and $4^{\prime}$ lined the suture of these plates to plate $3^{\prime}$ (Figs 10c,12c,d). Ventrally, in elongation of the rim around the pore plate, a minor ridge at times and in different development lined the sutures of the first apical plate with plates $2^{\prime}$ and $4^{\prime}$ (Fig. 12b). In the middle of the ventral area of the pore plate, there was a small X-plate with a characteristic three dimensional structure, which as a thin 
finger-like protrusion contacted the apical cover plate (Fig. 12a,b).

Among the six postcingular plates, plate $5^{\prime \prime \prime}$ was the widest, and plate $1^{\prime \prime \prime}$ was the narrowest (Fig. 10d). The two antapical plates were of different size (Fig. 10d), with the larger plate $2^{\prime \prime \prime \prime}$ bearing the short antapical spine which lay almost in the middle of the sagittal plain (Fig. 10a,b).
The deeply excavated and broad cingulum was composed of six plates. Plates C1 - C5 were of comparable size, but plate $\mathrm{C} 6$ was distinctly narrower. The location of cingular plates matched the location of their respective precingular plates (Fig. 10a,b). On plate $\mathrm{C} 1$ there was a ridge lining the growth band of $\mathrm{C} 1$ along the suture with the Sa plate (arrow in Fig. 12f ).
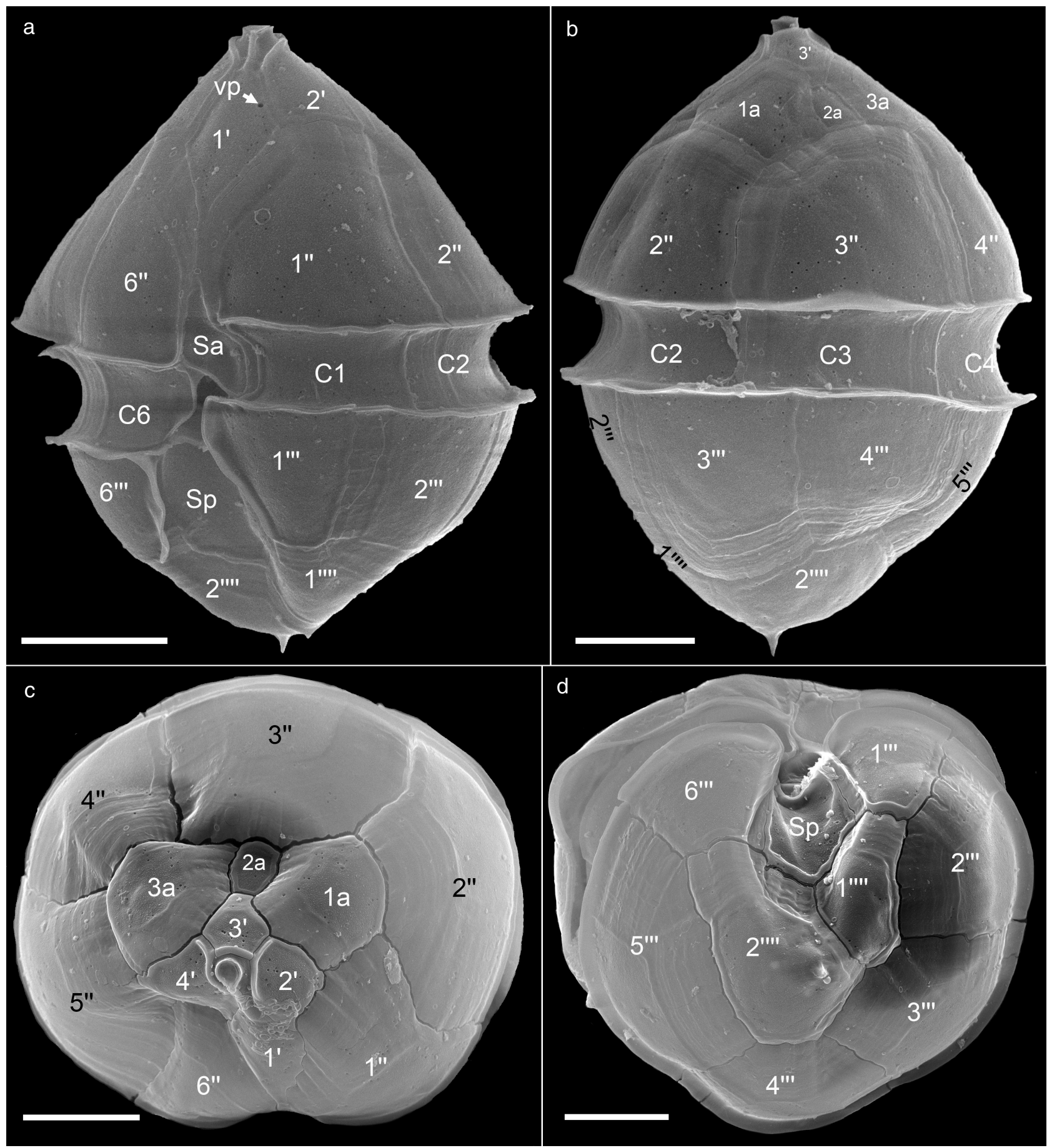

Fig. 10. Azadinium asperum sp. nov. SEM micrographs of different cells in (a) ventral view, (b) dorsal view, (c) apical view, and (d) antapical view. vp, ventral pore. Scale bars: $5 \mu \mathrm{m}$. 


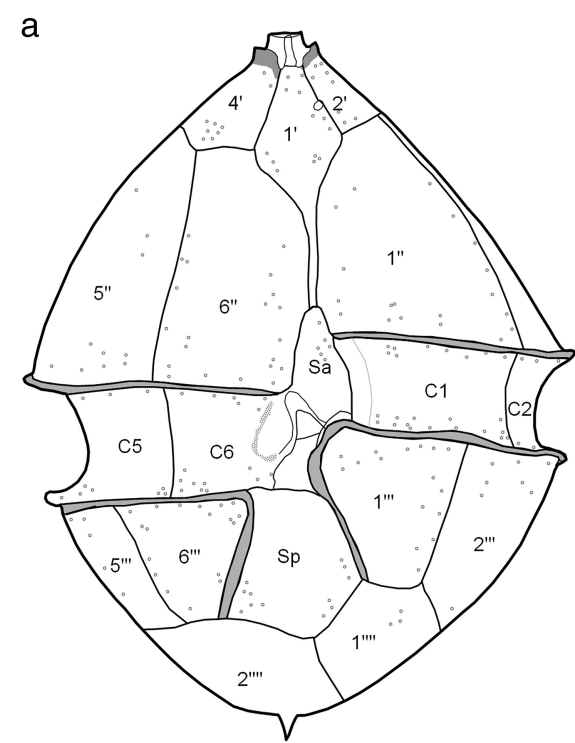

b
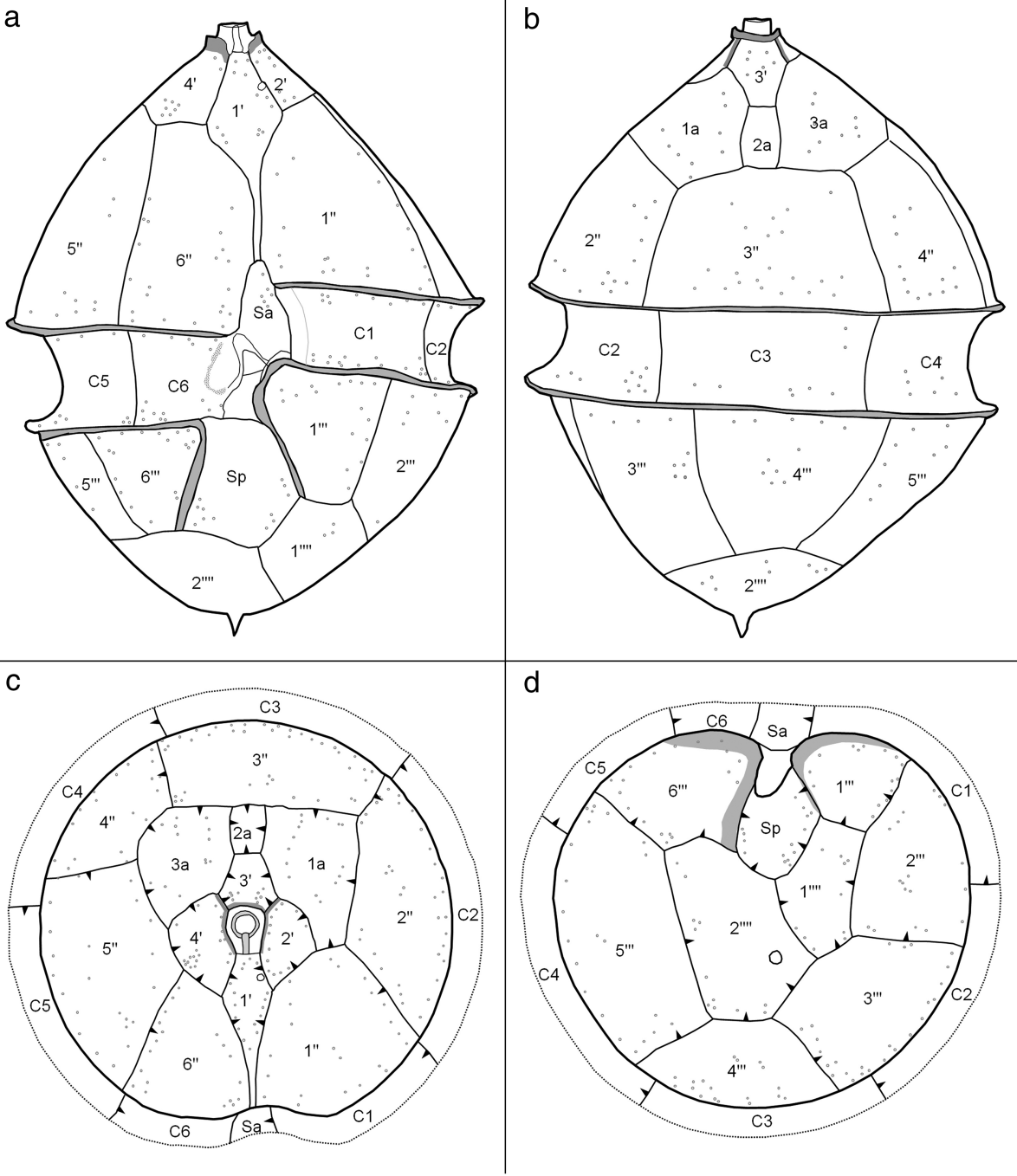

Fig. 11. Thecal plate pattern (schematic) of Azadinium asperum sp. nov. (a) Ventral view. (b) Dorsal view. (c) Apical view. (d) Antapical view. Plate labels according to the Kofoidian system. Abbreviations of sulcal plates: Sa, anterior sulcal plate; Sp, posterior sulcal plate. Arrowheads in $\mathrm{c}$ and $\mathrm{d}$ indicate direction of plate overlap.
The deeply concave sulcus (Figs $10 a, 12 e, f$ ) consisted of five plates. The large anterior sulcal plate (Sa) slightly extended into the epitheca whereas the large posterior sulcal plate (Sp) extended about one-half of the distance from the cingulum to the antapex. The left sulcal plate (Ss) was broad, located anterior to $\mathrm{Sp}$ and ran along the line from plate $\mathrm{C} 1$ to C6. The concave central indentation was made of two smaller sulcal plates Sm and Sd (Fig. 12e,f).

On most of the plates, broad and finely striated growth bands along certain sutures were visible (Figs 10,12d). Remaining parts of the plates were slightly raspy with a finegrained appearance (e.g. Fig. 12a). Almost all plates had a large number of small (about $0.1 \mu \mathrm{m}$ diameter) thecal pores with number and position as indicated in Figure 11. Of the clearly visible plates (i.e. excluding the small sulcal plates) only plate $2 a$ was consistently free of pores.

Growth bands and position of ridges along plate sutures identified the plate overlap pattern (Fig. 11c,d) and plates $3^{\prime \prime}$, $\mathrm{C} 3$, and $4^{\prime \prime \prime}$ as keystone plates of the precingular, cingular, and postcingular series, respectively.

For $A z$. asperum there were only 16 cells/fragments observed and among those limited number of observations, there were no deviating plate number. Variability in the contact of plate $1^{\prime \prime}$ and 1 a has been mentioned before.

\section{Other Amphidomatacean records}

Amphidoma parvula: Other than the species described above and the species described by Tillmann and Akselman (2016) from the same samples, there were observations on a total of 24 cells/fragments of the recently described species Amphidoma parvula Tillmann \& Gottschling (Figs S1,S2 in the Supporting Information). These cells in all respects conformed to the descriptions of the type culture. No ventral depression could be seen. A small field of pores in varying number and arrangements (Fig. S2J-L in the Supporting Information) was present on plate $2^{\prime \prime \prime \prime}$. Field specimens were used to elucidate the plate overlap pattern of Am. parvula (Fig. S3 in the Supporting Information).

Unclassified cells: A few cells/fragments were observed whose identification and/or classification was unclear. One cell of Azadinium was observed (Azadinium sp. 1, Fig. 13a,b) which in some aspects (size, shape, presence of a rough plate surface) resembled $A z$. asperum. However, here the ventral pore was differently located on the left side of plate $1^{\prime}$ at the suture to plate $1^{\prime \prime}$. Moreover, plate $2^{\prime}$ was very small, and there was a broad contact of plate $1 \mathrm{a}$ with the first apical plate (Fig. 13b). The hypotheca of this cell was hidden. Another cell of Azadinium (Azadinium sp. 2, Fig. 13c,d), also 


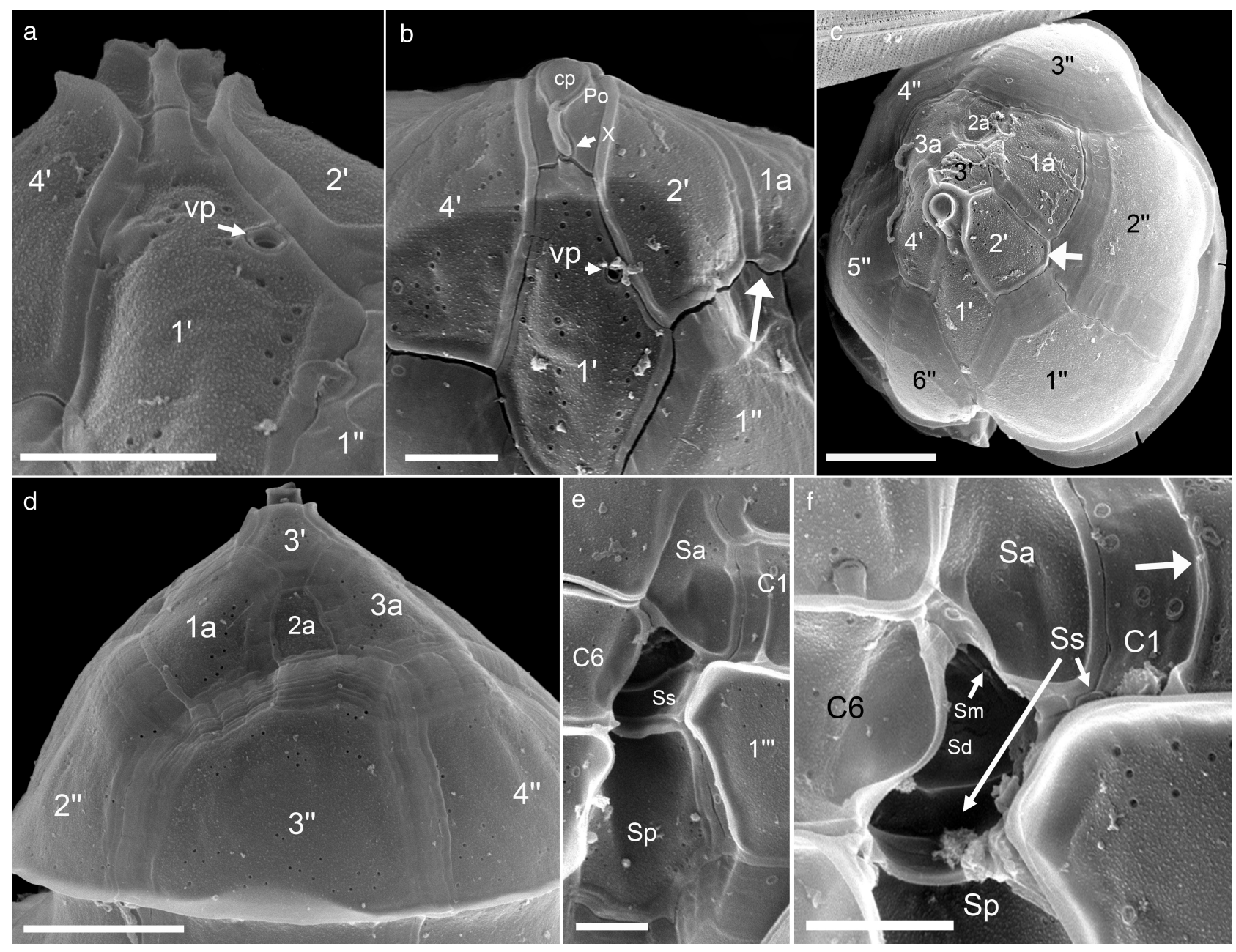

Fig. 12. Azadinium asperum sp. nov. SEM micrographs of different cells. (a, b) Apical plates and APC in ventral view showing the position of the ventral pore (vp). Note that in (b) there is contact between plate $1^{\prime \prime}$ and 1 a (wide arrow). (c) Epithecal plates in apical view. Note that there is no contact of plate $1^{\prime \prime}$ and 1 a (wide arrow). (d) Detailed view of epithecal plates in dorsal view. (e, $f$ ) Detailed view of the sulcal plate arrangement. Note the ridge lining the growth band of $\mathrm{C} 1$ towards the anterior sulcal plate (wide arrow in $f$ ). $c p, c o v e r$ plate; Po, pore plate; Sa, anterior sulcal plate; Sp, posterior sulcal plate; Ss, left sulcal plate; Sm, median sulcal plate; Sd, right sulcal plate; X, X-plate. Scale bars: $2 \mu \mathrm{m}$ (a, b, e, f) or $5 \mu \mathrm{m}$ (c, d).

had a rough plate surface and a ventral pore position on the left side of plate $1^{\prime}$ to the suture with plate $1^{\prime \prime}$. However, here plate $2^{\prime}$ was large (and thus plate $1^{\prime}$ in its upper part was more symmetrical), and there was no contact of plate 1 a with $1^{\prime}$ (Fig. 13d). This cell had a very small antapical spine (Fig. 13c).

Two observed hypothecal fragments differed from other species described from the sample. They were of very small size, had a very pronounced antapical spine, an elongated plate $\mathrm{Sa}$ and a reduced number of pores on the precingular plate (Fig. 13e,f).

Another cell (Amphidoma sp. 1, Fig. 13g, visible in dorsal view only) resembled $A m$. parvula (size, field of pores on plate $\left.2^{\prime \prime \prime \prime}\right)$, but here rows of pores bordered by a characteristic ridge on the apical plates were visible. Another wrinkled theca (Amphidoma sp. 2, Fig. 13h) also resembled Am. parvula with respect to the hypotheca (narrow plate $1^{\prime \prime \prime}$ ), but here it seemed as if a large apical plate was present on the right side of plate $1^{\prime}$. Another slightly wrinkled cell (Amphidoma sp. 3, Fig. 13i) likewise had a very narrow plate $1^{\prime \prime \prime}$, but unlike $A m$. parvula and Am. alata had a large apical plate (with bulged rows of pores) adjacent to plate $1^{\prime}$.

One cell was seen which resembled Am. languida in some respects, but which was much more slender and had an almost rectangular shape of plate $1^{\prime}$ with very straight lines (Amphidoma sp. 4, Fig. 14a). For one cell of most likely Azadinium (available in dorsal view only, Azadinium sp. 3, Fig. 14b,c) and resembling $A z$. spinosum, the ventral pore was in an unusual position almost in the middle of plate $1^{\prime}$ (Fig. 14c). Finally, an epithecal fragment was observed with an Amphidoma-like APC (note that the cover plate was missing) but had only five apical plates of a general appearance different to all species described above (Amphidoma sp. 5, Fig. 14d).

\section{DISCUSSION}

The present paper adds to the notion that plankton spring bloom communities offshore along the Argentinean Shelf 

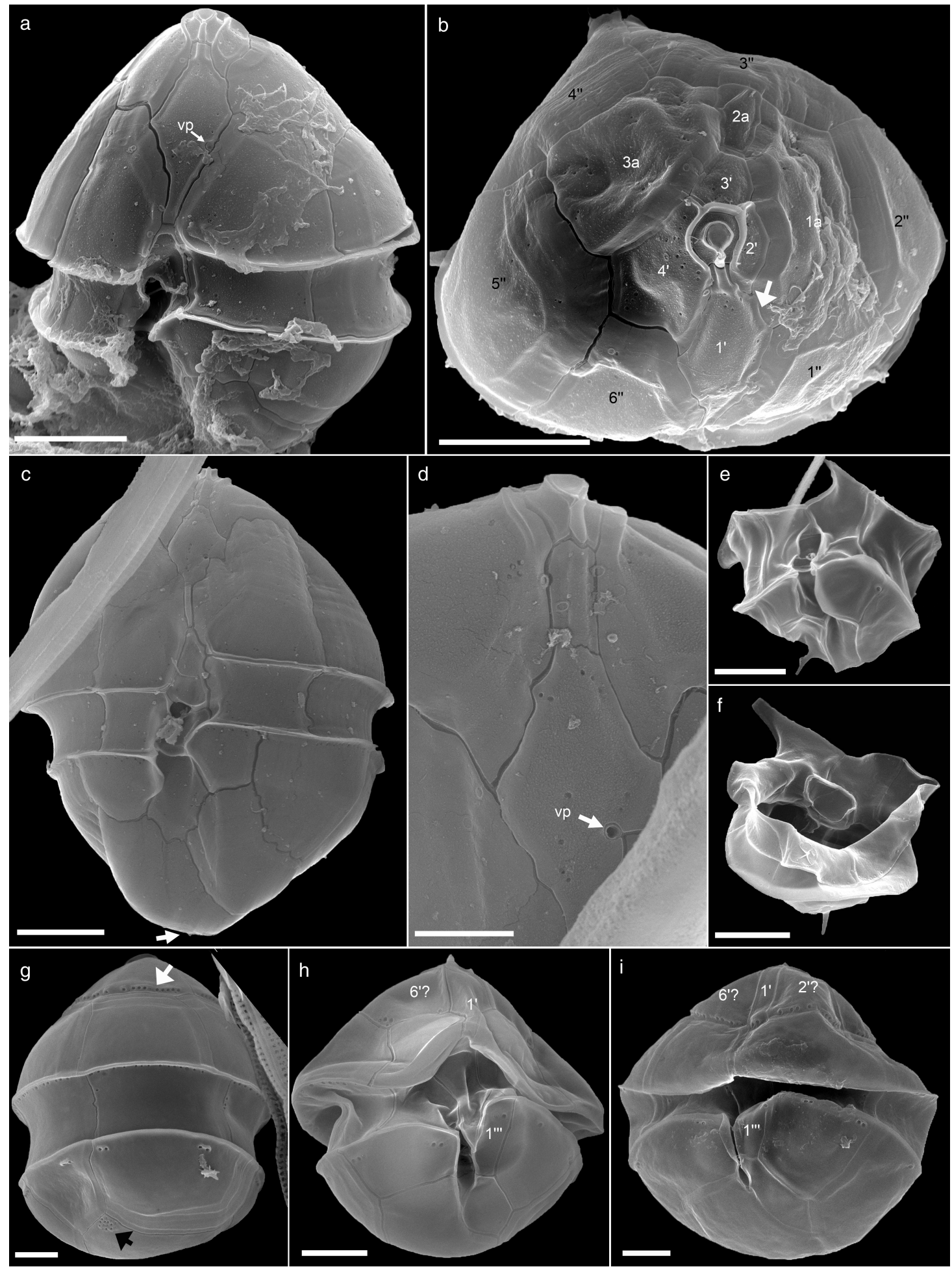

Fig. 13. SEM of cells or cell fragments of unclear species designation but assigned here with a tentative name and number. (a, b) Azadinium sp. 1 , same cell in dorsal (a) and apical view (b). Note the position of a ventral pore (vp) and the broad contact of plate 1 a and $1^{\prime}$ (wide arrow in b). (c, d) Azadinium sp. 2, same cell in dorsal view. Note the small antapical spine (arrow in c) and the position of the ventral pore (vp). (e, f) Two different hypothecal fragments interpreted to probably represent Azadinium concinnum. (g) Amphidoma sp. 1, dorsal view. Note the presence of rows of pores on the apical plates (white arrow) and a field of pores on plate $2^{\prime \prime \prime \prime}$ (black arrow). (h) Amphidoma sp. 2, ventral view. Note the narrow plate $1^{\prime \prime \prime}$ and a large apical plate (presumably plate $6^{\prime}$ ) present on the right side of plate $1^{\prime}$. (i) Amphidoma sp. 3, ventral view. Note the narrow plate $1^{\prime \prime \prime}$ and large apical plates (presumably plates $2^{\prime}$ and $6^{\prime}$, both with bulged rows of pores) adjacent to plate $1^{\prime}$. Scale bars: $5 \mu \mathrm{m}(\mathrm{a}-\mathrm{c})$ or $2 \mu \mathrm{m}(\mathrm{d}-\mathrm{i})$. 
Fig. 14. SEM of cells or cell fragments of unclear species designation but assigned here with a tentative name and number. (a) Amphidoma sp. 4, ventral view of a cell likely to be Amphidoma. (b, c) Azadinium sp. 3, same cell. Note the presence of an antapical spine in $b$ and the position of the ventral pore (vp) anterior inside plate $1^{\prime}$. (d) Amphidoma sp. 4, apical view of a cell of unclear designation showing five apical plates. Note the APC structure typical for Amphidomataceae (the cover plate is missing or rather sunken) with the $\mathrm{X}$ plate. Scale bars: $2 \mu \mathrm{m}$ (a, b, d) or $1 \mu \mathrm{m}(\mathrm{c})$.
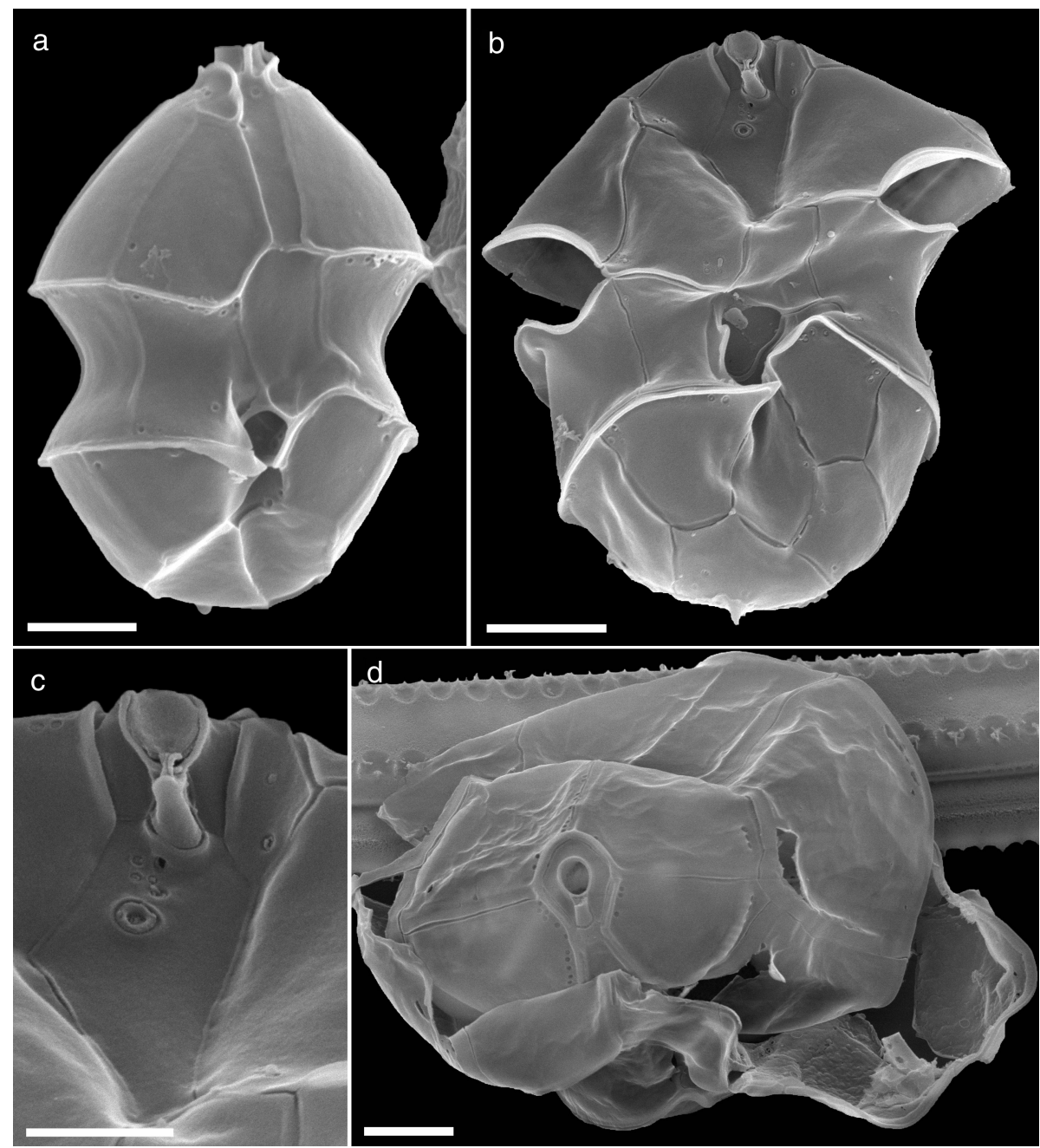

break exhibit a high diversity of Amphidomataceae species. It is now known that the dominant species in the spring 1991 bloom, initially described as $A z$. cf. spinosum (Akselman \& Negri 2012), is a new species $A z$. luciferelloides (Tillmann \& Akselman 2016). Moreover, this bloom also contained significant numbers of $A z$. spinosum, Az. dalianense, Az. dexteroporum and $A m$. languida as well (Tillmann \& Akselman 2016). Here we continue this study by presenting and describing other Amphidomataceae present in this sample. Cells of four species not reported before were encountered in sufficiently large numbers $(93,96,51,16$ for Am. trioculata, Am. alata, Am. cyclops and $A z$. asperum, respectively) to facilitate a detailed morphological analysis. All four of these species without doubt are members of the Amphidomataceae, sharing the characteristic number of six plates each in the precingular, cingular, and postcingular series, the arrangement of sulcal plates (with the left sulcal plate running across from the first to the last cingular plate), the peculiar morphology of the apical pore complex (presence of an X-plate with a characteristic finger-like extension connected to the cover plate), and the same plate overlap pattern characteristic for species of the Amphidomataceae (Tillmann et al. 2014a). Three of the species were assigned to Amphidoma as inferred from the plate pattern, which conform with the pattern described as characteristic for the genus: i.e. the presence of six apical plates and a lack of epithecal intercalary plates. In contrast, the epithecal plate pattern of the fourth new species with four apical and three anterior intercalary plates clearly indicate that this species requires assignment to Azadinium.

Azadinium asperum sp. nov. possesses a distinctive and unique combination of features that unambiguously differentiate this species from other Azadinium. These include the characteristically rough and slightly granular surface of thecal plates, a feature that is unique among all described Azadinium species. Moreover, with a cell length of $>20 \mu \mathrm{m}, A z$. asperum is distinctly larger than almost all other Azadinium (Tillmann et al. 2014a; Tillmann \& Akselman 2016; Luo et al. 2017). Both varieties of Az. caudatum are also well above $20 \mu \mathrm{m}$ in cell length, but have a different shape, an antapical horn bearing the antapical spine, and a different position of the ventral pore (Nézan et al. 2012). Previous work on the 12 previously described species of Azadinium confirms that the morphological features most significant for species differentiation are the position of the ventral pore, the number and arrangement of apical and intercalary plates, and the presence/absence of an antapical spine. With the ventral pore located on the left site of the apical pore, Az. asperum differs from Az. caudatum, Az. concinnum Tillmann \& Nézan, Az. 
dexteroporum, Az. Iuciferelloides and Az. zhuanum Z. Luo, Tillmann \& H. Gu, where the ventral pore is located on the right site of the apical pore (see table 3 in Tillmann et al. 2014a). Among the remaining species, Az. poporum, Az. dalianense, Az. triniatum Tillmann \& Nézan, and Az. cuneatum Tillmann \& Nézan, all have the ventral pore located at or inside the apical pore plate. Species that have a position of the ventral pore somewhat similar to $A z$. asperum (i.e. on the cell's left side of plate $1^{\prime}$ ) are $A z$. spinosum, Az. obesum Tillmann \& Elbrächter, and Az. polongum Tillmann. Among these, however, $A z$. asperum is the only species where the ventral pore is located on the suture of plate $1^{\prime}$ and $2^{\prime}$ and not of the suture of plate $1^{\prime}$ and $1^{\prime \prime}$ (Table 1 ). All of these features thus allow a clear morphological differentiation of $A z$. asperum from all other Azadinium and justify its description as a new species.

A differential diagnosis of species of Amphidoma is more complex, because five of the species were described without illustrations by Kofoid and Michener (1911). Nevertheless, even for these species, the fairly detailed verbal descriptions in the protologue allow a clear differentiation of the new species of Amphidoma (Table 2). An oval shape differentiates Am. trioculata from most other Amphidoma with biconical and/or elongate shapes. Am. trioculata in many aspects is similar to Am. languida, but it is significantly larger and has a broader cingulum (Table 2). The other ovoid species, Am. cyclops, is similar in size, but lacks the antapical pore (Table 2). Am. alata shares a broad biconical shape with a number of Amphidoma species but is unique by its conspicuous wing-like sulcal list. Like Am. trioculata, Am. cyclops is one of the few Amphidoma species with oval shape (Table 2). It differs from the ovoid Am. parvula by its larger size and the hemispherical versus flat hypotheca, and from the ovoid $A m$. trioculata by its lack of an antapical pore. Moreover, the ventral depression of Am. cyclops is larger than that of Am. trioculata. Finally, the hypotheca of Am. cyclops has list-like thickenings lining a number of sutures of both antapical plates in a unique way among species of Amphidoma.

All new species described here share the fine structure of the APC (i.e. presence of a centrally located X-plate with a characteristic external extension contacting the cover plate) and the arrangement of the sulcal region as elucidated for all species of Azadinium and for Am. languida and Am. parvula, the only two species of Amphidoma that have been subjected to detailed analysis by SEM. Although the smaller sulcal plates for the new species described here were partly hidden and difficult to resolve, the present study confirms the presence of five sulcal plates in the very characteristic arrangement as described for species of Azadinium (Tillmann et al. $2014 b$ ), i.e. with a left sulcal plate running horizontally from $\mathrm{C} 1$ to $\mathrm{C} 6$, and with two small plates (note that these two plates could not be unambiguously shown for Am. alata) forming the internally vaulted cavity. This characteristic arrangement of sulcal plates is one of the morphological distinctions that support the close relationship of both genera in phylogenetic trees.

Such thecal details are imperfectly known for the older species. The presence of the minute X-plate was not mentioned in most of the older Amphidoma species descriptions, but it was noted and depicted for Am. nucula Stein by Balech (1971) as a 'diminuta canaleta' posterior to the pore plate.
With respect of sulcal plates, the number of plates (if resolved at all) in old descriptions ranges from three (Dodge \& Saunders 1985) to four (Balech 1971). However, it is suggested that both the presence of an X-plate and the universal presence of five sulcal plates will be confirmed when detailed SEM analysis is applied to these old species.

A feature found so far for all species of Azadinium, including the new species $A z$. asperum, is the presence of a ventral pore, an opening distinctly larger than regular thecal pores. It is surrounded by a platelet-like structure, and has different and species-specific positions on the ventral part of the epitheca. Such a ventral pore is also present in Am. languida (Tillmann et al. 2012) but is lacking in the described new species Am. parvula (Tillmann et al. 2018), which is thus the first species of Amphidomataceae investigated with modern high resolution SEM that is missing such a pore. The present study shows that $A m$. alata likewise lacks a ventral pore. For Am. trioculata the ventral pore is clearly present on the anterior right side of plate $1^{\prime}$, whereas the presence/absence of such a pore could not be clarified for Am. cyclops because of the overlaying edges of the neighboring plates $2^{\prime}$ and $6^{\prime}$ in that region.

The presence/absence of a ventral pore in the older species of Amphidoma cannot be determined, because they were described on the basis of light microscopy. The situation is especially difficult, because in older light microscopic descriptions, the ventral pore might be confused with what is now regarded as the ventral depression. In fact, the presence of a 'ventral pore' has been reported for a few of the older Amphidoma species. It is described and/or depicted as a round structure located mid-ventrally, just above the cingulum at the posterior tip of the first apical plate (Kofoid 1907). Such a structure was also noted by Balech (1971) in his detailed study of Am. nucula, where he described a round to funnel shaped structure as a 'head shaped end [of plate Sa] that gets into the epitheca'. As suggested previously (Tillmann et al. 2018), this structure likely corresponds to the 'ventral depression' reported before for Am. languida, Am. parvula, and now for Am. trioculata and Am. cyclops.

For the field specimens of $A m$. trioculata, such a ventral depression was always present, albeit with slightly different shapes and characteristics (Fig. 3f-h). For Am. cyclops, the ventral depression was always present with roughly the same size and shape, whereas for field specimens of Am. alata no clear indications of such a structure were present. In contrast, for various strains of Am. languida in cultures, it was emphasized that a ventral depression was variable among cells ranging from distinctly developed to faintly expressed, and in other cases it was almost indiscernible (Tillmann et al. 2015, 2017a). Likewise, for some but not all cells of Am. languida observed in the 1991 Argentinean bloom (Tillmann \& Akselman 2016), a roundish structure at the end of plate $\mathrm{Sa}$ is allusively visible. For the culture of Am. parvula obtained from the 2015 Argentinean spring bloom, shape and characteristics of this ventral depression were variable among cells, ranging from distinctly developed through faintly expressed, and in many cases it was either not present or almost indiscernible (Tillmann et al. 2018). For the few field specimens of Am. parvula observed here in the 1991 sample (Fig. S1 in the Supporting Information) a roundish depression at the anterior tip of the anterior sulcal plate was rarely - if at all - suggestively noticeable. In conclusion, the present observation of a 


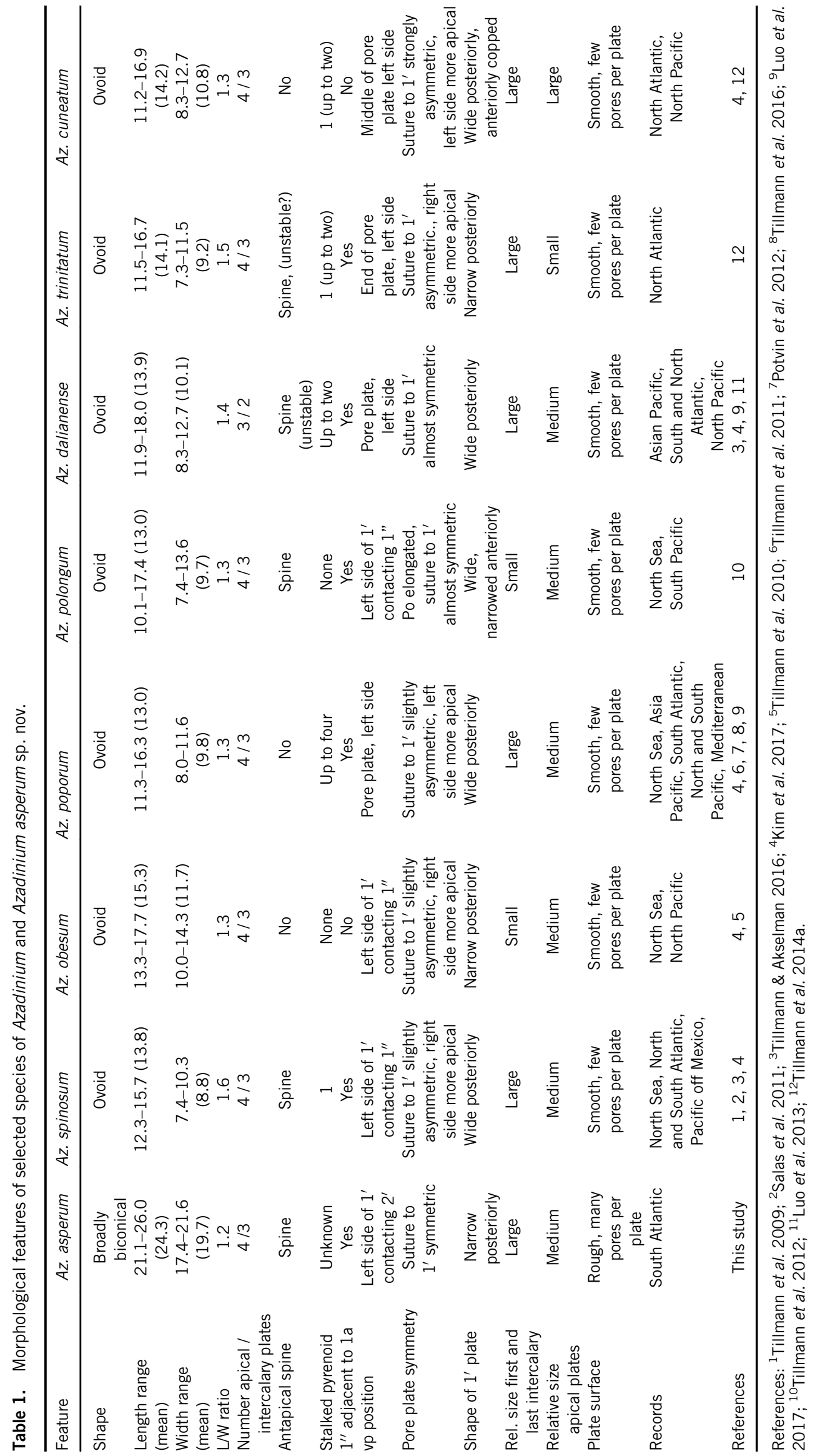




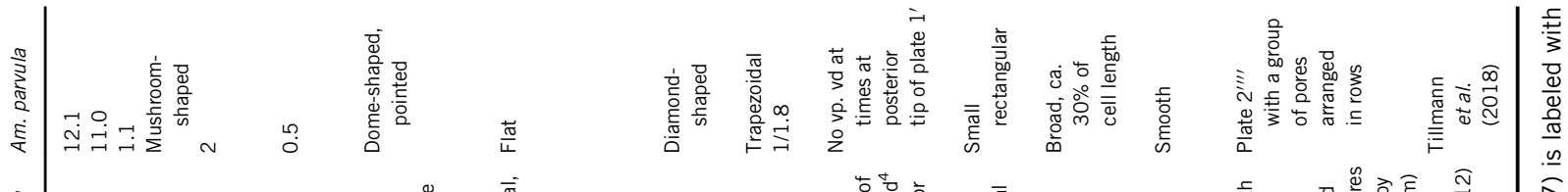

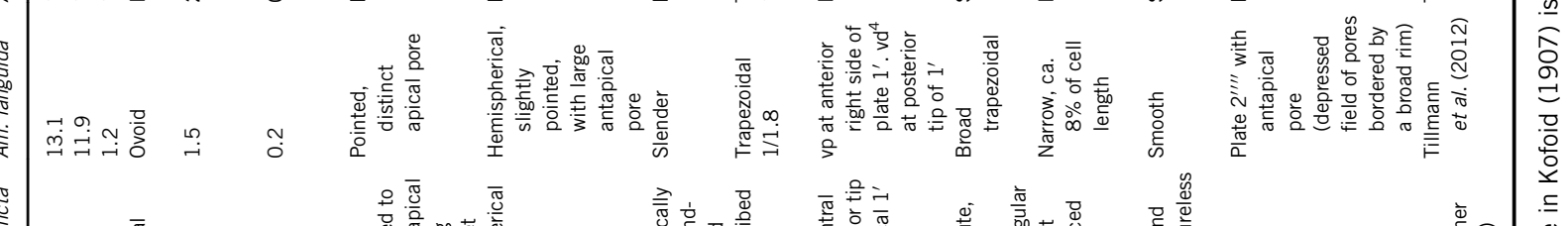

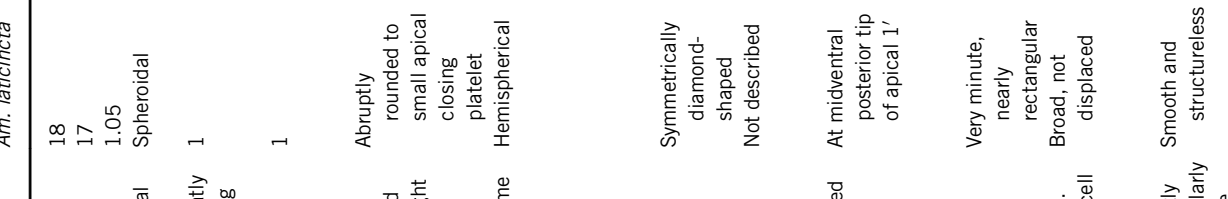

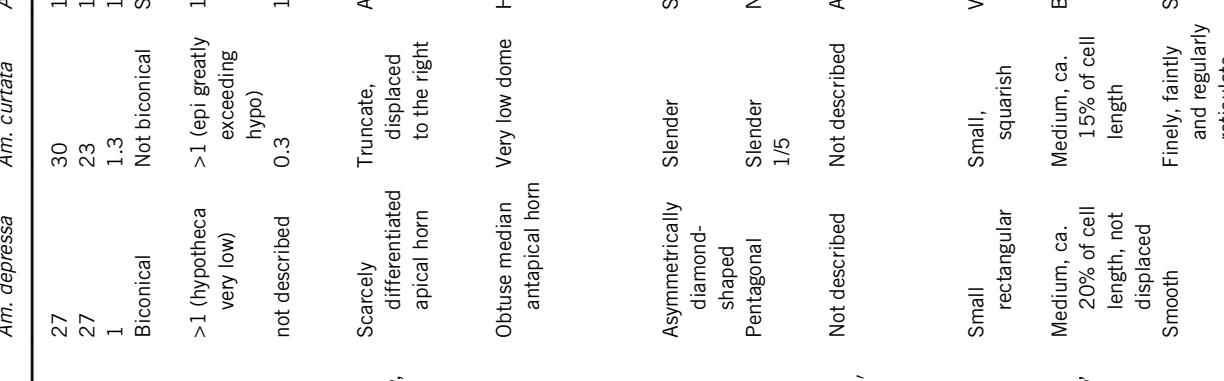

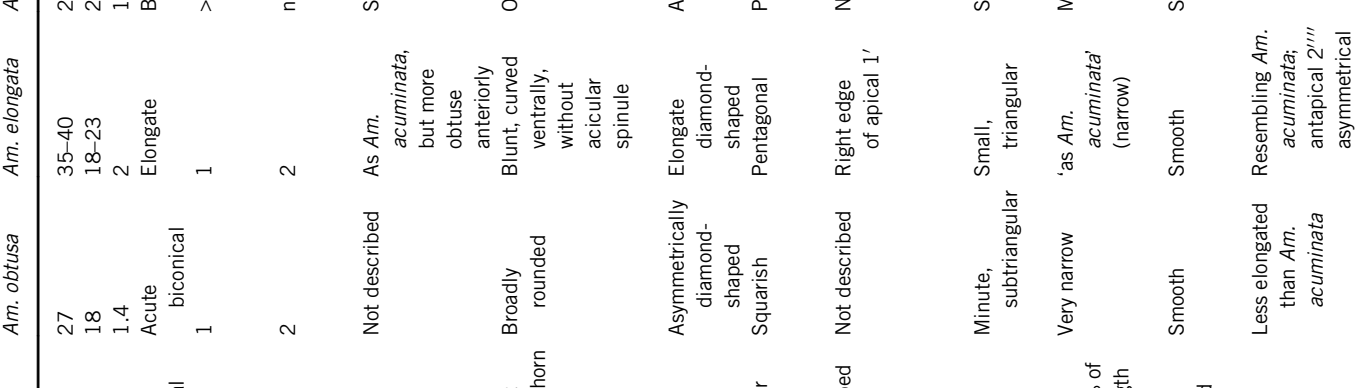

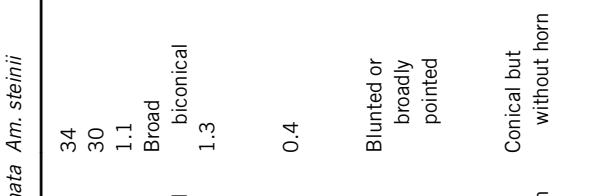

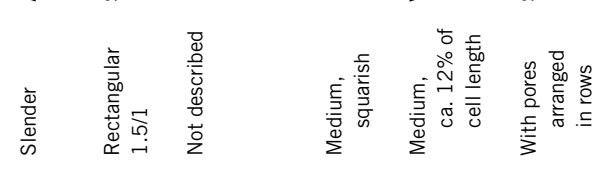

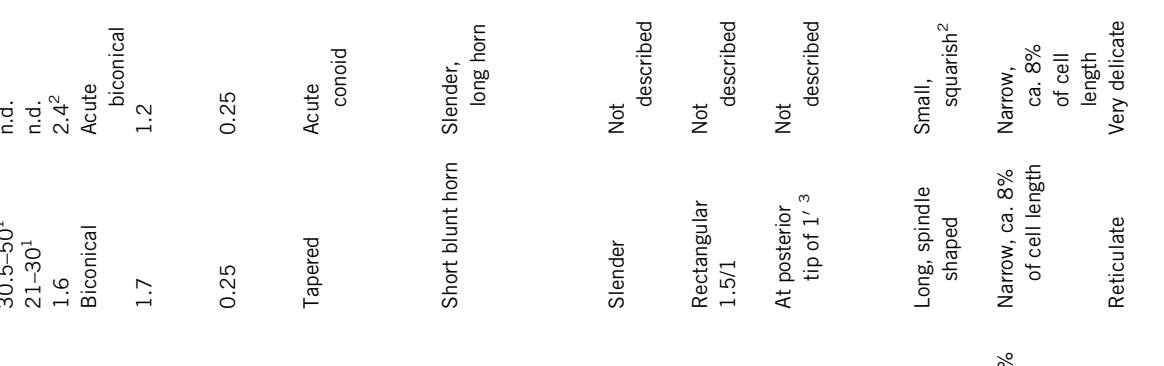

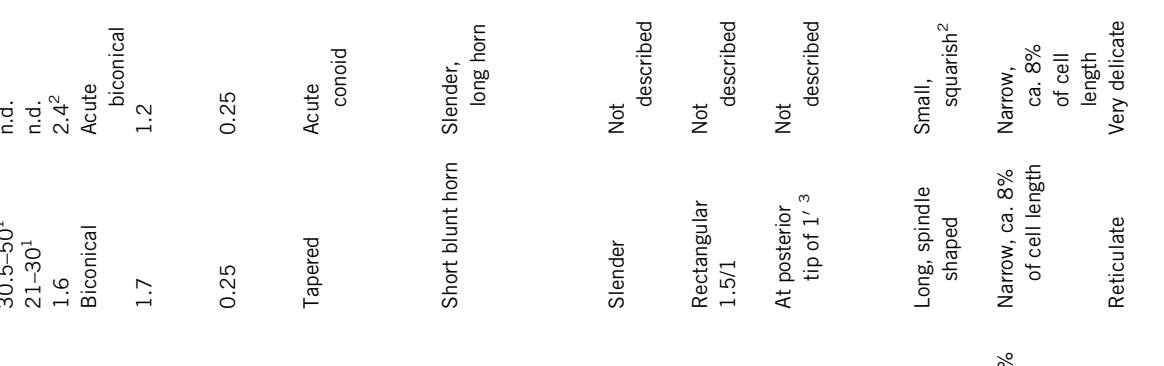

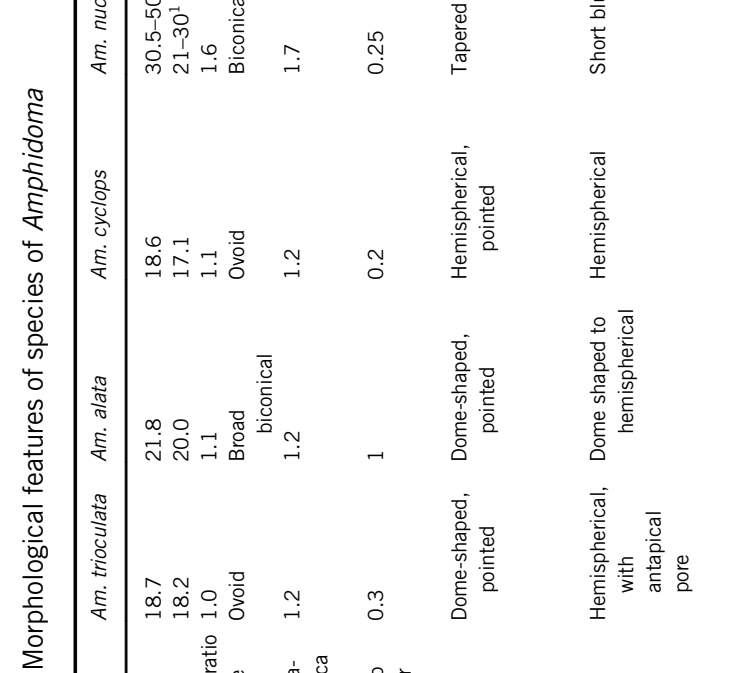

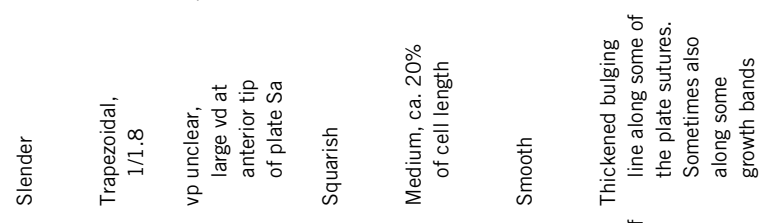
我离

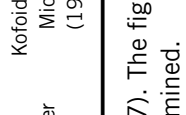

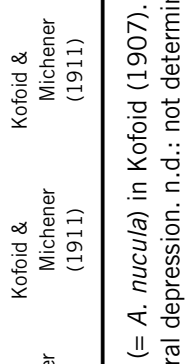

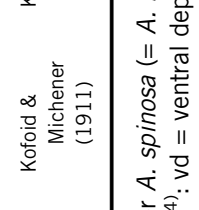

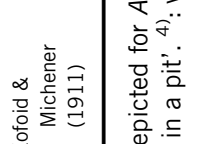

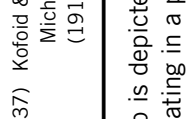

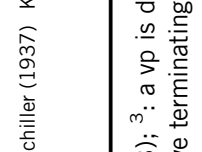

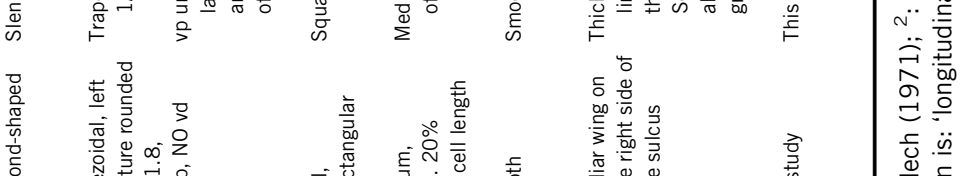

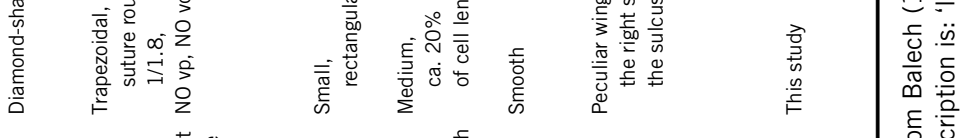

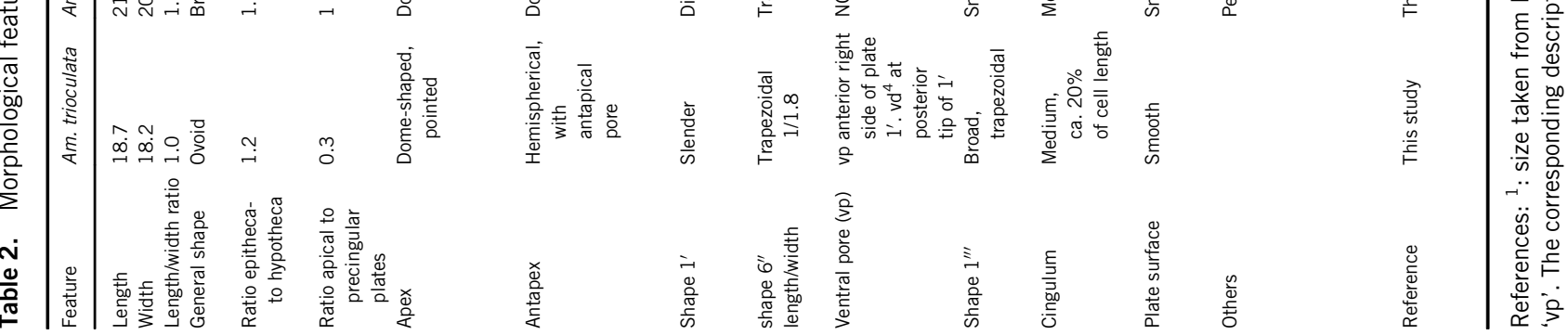


ventral depression in Am. trioculata and Am. cyclops, together with the description of such a structure for some of the old Amphidoma species (Table 2), indicate that a ventral depression is a common morphological feature of Amphidoma. However, given its variable characteristics and development at least for some species, its diagnostic value seems to be limited.

In light of the new detailed descriptions presented here, the comparison of species of Amphidoma (Table 2) reveals a potential subdivision into two groups. Group I encompasses species which have (a) a slender shape of plate $1^{\prime}$ and (b) a length ratio of apical to precingular plates $<0.5$. In contrast, species of group II have (a) a diamond-shaped plate $1^{\prime}$, (b) a length ratio of apical to precingular plates of $>0.5$ (Table 2). The new species Am. trioculata and Am. cyclops can be assigned to group I, whereas $A m$. alata is a member of group II. From the data presented here is seems likely that species of group I also share the presence of a ventral pore (as inferred from its documented presence in $\mathrm{Am}$. languida and Am. trioculata), whereas species of group II lack such a pore (as inferred from observations of Am. parvula and Am. alata). Moreover, species of group II tend to have a minute plate $1^{\prime \prime \prime}$ compared to a more broad shape of plate $1^{\prime \prime \prime}$ in group I. DNA sequence data of more Amphidoma species are needed to evaluate if such a morphological subdivision within Amphidoma is also reflected in phylogenetic trees.

The new descriptions further indicate that species of Azadinium and Amphidoma slightly but consistently (at least for recently studies species of Amphidoma) differ in the detailed arrangement of the median sulcal area. For species of Amphidoma, the contact between plate Sa and C6 is long and almost covers the whole width of the cingulum. In contrast, for species of Azadinium, this contact is more narrow, making much less than one-third of the cingulum width and causing a more anterior location of the inverted cavity where the flagella emerge.

With now five species of Azadinium and five species of Amphidoma newly recorded from the spring plankton community of the Argentinean Shelf (Tillmann \& Akselman 2016; this study), the diversity of the Amphidomataceae in this area is notable. In order to roughly estimate the relevance of the new species in terms of abundance, the previous estimation of the overall cell density of small thecate dinophytes of $2.5 \times 10^{6}$ cells L ${ }^{-1}$ (Akselman \& Negri 2012) can be used. Taking into account percentages estimated by electron microscopy to differentiate between $A z$. luciferelloides and other Amphidomataceae (Tillmann \& Akselman 2016), cell densities of the new species in the range of about $7-40 \times 10^{3}$ cells $L^{-1}$ are significant. Planktonic dinophytes of the South Atlantic of Argentina were intensively studied by Enrique Balech (e.g. Balech 1988) almost 50 years ago, but given their delicate nature and small size, it is quite likely that Amphidomataceae of the offshore shelf break were simply overlooked in the past. Given the present records of a few more single cells attributable to Amphidomataceae but not yet to one of the described species (Figs 13-14), it is likely that the diversity of the group is still not fully explored. Continued attempts to sample Argentinean shelf break spring blooms are needed, particularly to establish cultures and ultimately for molecular and toxinological characterization of all the species.

\section{ACKNOWLEDGMENTS}

This study would not have been possible without help and support from Ruth Akselman from Argentina, who first studied Azadinium blooms back in the early 1990s; Ruth kindly provided the fixed old bloom samples. Steve Pueppke kindly corrected the English. Financial support was provided by the PACES research program of the Alfred Wegener Institute as part of the Helmholtz Foundation initiative in Earth and Environment.

\section{REFERENCES}

Akselman, R. and Negri, R. M. 2012. Blooms of Azadinium cf. spinosum Elbrächter et Tillmann (Dinophyceae) in northern shelf waters of Argentina, Southwestern Atlantic. Harmful Algae 19: 30-8.

Akselman, R., Negri, R. M. and Cozzolino, E. 2014. Azadinium (Amphidomataceae, Dinophyceae) in the Southwest Atlantic: in situ and satellite observations. Rev. Biol. Mar. Oceanog. 49: 511-26.

Álvarez, G., Uribe, E., Ávalos, P., Mariño, C. and Blanco, J. 2010. First identification of azaspiracid and spirolides in Mesodesma donacium and Mulinia edulis from Northern Chile. Toxicon 55: 638-41.

Amzil, Z., Sibat, M., Royer, F. and Savar, V. 2008. First report on azaspiracid and yessotoxin groups detection in French shellfish. Toxicon 52: 39-48.

Bacchiocchi, S., Siracusa, M., Ruzzi, A. et al. 2015. Two-year study of lipophilic marine toxin profile in mussels of the North-central Adriatic Sea: first report of azaspiracids in Mediterranean seafood. Toxicon 108: 115-25.

Balech, E. 1971. Microplancton del Atlántico ecuatorial oeste (Equalant I), Vol. 654. República Argentina, Armada Argentina Servico de Hidrografía Naval, Buenos Aires, pp. 1-103.

Balech, E. 1988. Los dinoflagellados del Atlántico sudoccidental, Vol. 1. Publicaciones Especiales Instituto Español de Oceanografia, pp. 1-310.

Cavalcante, K. P., Susini-Ribeiro, S. M. M. and Tillmann, U. 2018. First detection of Azadinium spp. (Amphidomataceae, Dinophyceae) in tropical coastal waters of Brazil. Braz. J. Bot. 41: 209-18.

Dodge, J. D. and Saunders, R. D. 1985. An SEM study of Amphidoma nucula (Dinophyceae) and description of the thecal plates in A. caudata. Arch. Protistenkd. 129: 89-99.

Halldal, P. 1953. Phytoplankton investigations from Weather Ship M in the Norwegian Sea, 1948-49. Hvalrådets Skrifter 38: 1-91.

Kim, J. W., Tillmann, U., Adams, N. G. et al. 2017. Identification of Azadinium species and a new azaspiracid from Azadinium poporum in Puget Sound, Washington State, USA. Harmful Algae 68: 152-67.

Kofoid, C. A. 1907. Reports on the scientific results of the expedition to the eastern tropical Pacific, in charge of Alexander Aggassiz, by the U.S. Fish Commission steamer "Albatross", from October, 1904, to March, 1905, Lieut.-Commander L.M. Garrett, U.S.N., commanding. IX. New species of dinoflagellates. Bull. Mus. Comp. Zool. 50: 163-207.

Kofoid, C. A. and Michener, J. R. 1911. Reports on the scientific results of the expedition to the Eastern Tropical Pacific, in Charge of Alexander Agassiz, by the U.S. Fish Commission Steamer "ALBATROSS", from October 1904, to March, 1906, Lieut. L.M. Garrett, U.S.N., Commanding . XXII. New genera and species of Dinoflagellates. Bull. Mus. Comp. Zool. 54: 267-302.

Krock, B., Tillmann, U., Voß, D. et al. 2012. New azaspiracids in Amphidomataceae (Dinophyceae): proposed structures. Toxicon 60: 830-9. 
Luo, Z., Krock, B., Mertens, K. et al. 2017. Adding new pieces to the Azadinium (Dinophyceae) diversity and biogeography puzzle: nontoxigenic Azadinium zhuanum sp. nov. from China, toxigenic A. poporum from the Mediterranean, and a non-toxigenic A. dalianense from the French Atlantic. Harmful Algae 66: 65-78.

Nézan, E., Tillmann, U., Bilien, G. et al. 2012. Taxonomic revision of the dinoflagellate Amphidoma caudata: transfer to the genus Azadinium (Dinophyceae) and proposal of two varieties, based on morphological and molecular phylogenetic analyses. J. Phycol. 48: 925-39.

Potvin, E., Jeong, H. J., Kang, N. S. T., Tillmann, U. and Krock, B. 2012. First report of the photosynthetic dinoflagellate genus Azadinium in the Pacific Ocean: morphology and molecular characterizationof Azadinium cf. poporum. J. Eukaryot. Microbiol. 59: 145-56.

Rossi, R., Dell'Aversano, C., Krock, B. et al. 2017. Mediterranean Azadinium dexteroporum (Dinophyceae) produces AZA-35 and six novel azaspiracids: a structural study by a multi-platform mass spectrometry approach. Anal. Bioanal. Chem. 409: 1121-34.

Salas, R., Tillmann, U., John, U. et al. 2011. The role of Azadinium spinosum (Dinophyceae) in the production of Azaspiracid Shellfish Poisoning in mussels. Harmful Algae 10: 774-83.

Schiller, J. 1929. Über eine biologische und hydrographische Untersuchung des Oberflächenwassers im westlichen Mittelmeer. Botanisches Archiv 27: 381-419.

Schiller, J. 1933. Dinoflagellatae (Peridineae) in monographischer Behandlung. In Rabenhorst, L. (Ed.). Dr. L. Rabenhorst's Kryptogamen-Flora von Deutschland, Österreich und der Schweiz. Akademische Verlagsgesellschaft, Leipzig, pp. 1-615.

Smith, K. F., Rhodes, L., Harwood, D. T. et al. 2016. Detection of Azadinium poporum in New Zealand: the use of molecular tools to assist with species isolations. J. Appl. Phycol. 28: 1125-32.

Sournia, A. 1984. Classification at nomenclature de divers dinoflagellates marines (classe des Dinophyceae). Phycologia 23: 345-55.

Stein, F. 1883. Der Organismus der Infusionsthiere nach eigenen Forschungen in systematischer Reihenfolge bearbeitet. III. Abt. II. Hälfte. Der Organismus der Arthrodelen Flagellaten. W. Engelmann, Leipzig.

Taleb, H., Vale, P., Amanhir, R., Benhadouch, A., Sagou, R. and Chafik, A. 2006. First detection of azaspiracids in mussels in north West Africa. J. Shellfish. Res. 25: 1067-70.

Tillmann, U., Elbrächter, M., Krock, B., John, U. and Cembella, A. 2009. Azadinium spinosum gen. et sp. nov. (Dinophyceae) identified as a primary producer of azaspiracid toxins. Eur. J. Phycol. 44: $63-79$

Tillmann, U., Elbrächter, M., John, U. and Krock, B. 2011. A new non-toxic species in the dinoflagellate genus Azadinium: A. poporum sp. nov. Eur. J. Phycol. 46: 74-87.

Tillmann, U., Salas, R., Gottschling, M., Krock, B., O'Driscoll, D. and Elbrächter, M. 2012. Amphidoma languida sp. nov. (Dinophyceae) reveals a close relationship between Amphidoma and Azadinium. Protist 163: 701-19.

Tillmann, U., Gottschling, M., Nézan, E., Krock, B. and Bilien, G. 2014a. Morphological and molecular characterization of three new Azadinium species (Amphidomataceae, Dinophyceae) from the Irminger Sea. Protist 165: 417-44.

Tillmann, U., Salas, R., Jauffrais, T., Hess, P. and Silke, J. 2014b. AZA: the producing organisms - biology and trophic transfer. In Botana, L. M. (Ed.). Seafood and Freshwater Toxins. CRC Press, Boca Raton, FL, pp. 773-98.

Tillmann, U., Gottschling, M., Nézan, E. and Krock, B. 2015. First record of Azadinium dexteroporum and Amphidoma languida
(Amphidomataceae, Dinophyceae) from the Irminger Sea off Iceland. Marine Biodiv. Rec. 8: 1-11.

Tillmann, U. and Akselman, R. 2016. Revisiting the 1991 algal bloom in shelf waters off Argentina: Azadinium luciferelloides sp. nov. (Amphidomataceae, Dinophyceae) as the causative species in a diverse community of other amphidomataceans. Phycol. Res. 64: 160-75.

Tillmann, U., Borel, M., Barrera, F. et al. 2016. Azadinium poporum (Dinophyceae) from the South Atlantic off the Argentinean coast produce AZA-2. Harmful Algae 51: 40-55.

Tillmann, U. 2018. Amphidomataceae. In Shumway, S. E., Burkholder, J. A. and Morton, S. L. (Eds). Harmful Algae Blooms, A Compendium Desk Reference. Wiley-Blackwell, Hoboken, NJ. in press.

Tillmann, U., Gottschling, M., Guinder, V. and Krock, B. 2018. Amphidoma parvula (Amphidomataceae), a new planktonic dinophyte from the Argentine Sea. Eur. J. Phycol. 53: $14-28$.

Tillmann, U., Jaen, D., Fernandez, L. et al. 2017a. Amphidoma languida (Amphidomataceae, Dinophyceae) with a novel azaspiracid toxin profile identified as the cause of molluscan contamination at the Atlantic coast of southern Spain. Harmful Algae 62: 113-26.

Tillmann, U., Trefault, N., Krock, B., Parada-Pozo, G., De la Iglesia, R. and Vásquez, M. 2017b. Identification of Azadinium poporum (Dinophyceae) in the Southeast Pacific: morphology, molecular phylogeny, and azaspiracid profile characterization. J. Plankton Res. 39: 350-67.

Tillmann, U., Sánchez Ramírez, S., Krock, B. and Bernales Jiménez, A. 2017c. A bloom of Azadinium polongum in coastal waters off Peru. Rev. Biol. Mar. Oceanog. 52: 591-610.

Trainer, V. L., Moore, L., Bill, B. D. et al. 2013. Diarrhetic shellfish toxins and other lipophilic toxins of human health concern in Washington State. Mar. Drugs 11: 1815-35.

Turner, A. D. and Goya, A. B. 2015. Occurrence and profiles of lipophilic toxins in shellfish harvested from Argentina. Toxicon 102: $32-42$.

Yao, J., Tan, Z., Zhou, D., Guo, M., Xing, L. and Yang, S. 2010. Determination of azaspiracid-1 in shellfishes by liquid chromatography with tandem mass spectrometry. Chin. J. Chromatogr. 28: 363-7.

\section{SUPPORTING INFORMATION}

Additional Supporting Information may be found in the online version of this article at the publisher's web-site:

Fig. S1. SEM micrographs of Amphidoma parvula.

Fig. S2. SEM micrographs of Amphidoma parvula.

Fig. S3. Plate pattern (schematic) of Amphidoma parvula.

Fig. S4. SEM micrographs of Amphidoma trioculata sp. nov.

Fig. S5. SEM micrographs of Amphidoma alata sp. nov.

Fig. S6. SEM micrographs of Amphidoma cyclops sp. nov.

Fig. S7. SEM micrographs of Azadinium asperum sp. nov.

Fig. S8. SEM micrographs of Amphidoma spp., cells with deviating plate details. 